\title{
SAĞLIK SEKTÖRÜNDE ABC-VED AHP VE TOPSIS YÖNTEMLERİ KULLANILARAK ÇOK KRİTERLİ STOK SINIFLANDIRMASI
}

\author{
MULTI-CRITERIA INVENTORY CLASSIFICATION IN THE HEALTHCARE \\ SECTOR USING ABC-VED AHP AND TOPSIS METHODS
}

\section{Zehra BÖKER* Onur ÇETIN ${ }^{* *}$}

Öz

Günümüzde sağlık sektörü en önemli hizmet sektörlerinden biri durumundadır. Sağlık sektöründe hizmet veren hastanelerin, işletme maliyetlerinin önemli kısmını ilaç giderleri oluşturmaktadır. Hastanelerin daha iyi hizmet verebilmesi için stok kontrolünün sağlıklı yapılması gerekmektedir. Hem maliyet açısından hem de hastalar açısından hayati önem taşıyan ilaçların tespiti ve yönetimi hastanelerin asli görevlerindendir. Hastanelerdeki ilaç stoklarının kontrolünde çeşitli sınıflandırmalar bulundurmaktadır. En çok kullanılan yöntem ABC-VED yöntemidir. Bu yöntemde maliyet, tüketim ve kritiklik sınıflandırma kriterleri dikkate alınmaktadır. Diğer sektörlerde çok kriterli stok sınıflandırmasında tedarikçi ile ilgili faktörler de kullanılırken, sağlık sektöründe stok sınıflandırmasında bu üç kritere yeni bir kriter ekleyen çalışmalar sınırlıdır. Bu çalışmada bu üç kriterin yanında tedarikçi riski ile ilgili bir kriter de eklenerek ABC -VED, AHP ve TOPSIS yöntemleri ile sağlık sektöründe stok s1nıflandırması yapılması amaçlanmıştır. Maliyet, tüketim ve kritiklik kriterlerinin içinde bulunduğu ABC-VED yöntemiyle birlikte, hastanedeki ilaçların hem maliyet hem de hayati önem açısından stok sınıflandırması yapılmıştır. Ayrıca AHP yöntemi ile TOPSIS yöntemi kullanılarak ve tedarikçi riski ile ilgili bir kriter eklenerek yeniden ABC-VED Matris yöntemi oluşturulmuştur. Son olarak üçlü ABCVED yöntemiyle elde edilen sonuçlarla ABC-VED AHP ve TOPSIS yöntemleriyle elde edilen matris sonuçları kıyaslanmıştır.

\footnotetext{
* $\quad$ Trakya Üniversitesi, İșletme Bölümü, E-mail:zehra_boker@hotmail.com

** Trakya Üniversitesi, İşletme Bölümü, Email:onurcetin@trakya.edu.tr
} 
Anahtar Kelimeler: Sağlık Sektörü, ABC-VED, AHP, TOPSIS, Stok Kontrol.

\section{Abstract}

Health sector is one of the most important service sectors. The major part of the operating costs of the hospitals serving in the health sector is pharmaceutical expenses. In order for hospitals to provide better service, inventory control must be performed effectively. Identifying and managing medicines that are vital for patients is one of the main tasks of hospitals. There are various classifications for inventory control in health sector. The most known method for health sector is ABC-VED analysis which uses cost, demand and criticality as classification criteria. While many criteria including supplier criteria is used in inventory classification in other sectors, research using more than three criteria is limited in health sector. This research aims to conduct a multi criteria inventory classification in health sector using cost, demand, criticality, and supplier risk with ABC-VED, AHP and TOPSIS methods. Inventory classification is conducted by ABC-VED method using cost, demand and criticality criteria. In addition, the ABC-VED Matrix method was re-created by using AHP and TOPSIS methods by adding a new criteria regarding supplier risk. The results obtained by ABC-VED method and by ABC-VED, AHP and TOPSIS methods are compared.

Keywords: Healthcare sector, ABC-VED, AHP, TOPSIS, Inventory Control.

\section{GíRiş}

Sağlık işletmesi olarak hastanelerin en temel görevi, talep edilen sağlık hizmetlerini sağlayabilmektir. Hastaneler, ekonomik kaynakları sınırlı olduğundan, hizmet verirken bu kaynakları etkin olarak kullanmalıdırlar. Yapılan çalışmalara göre sağlık sektöründe stok maliyetleri \%10 ila \%18 arasında değişmektedir (Rachmania \& Basri, 2013). Bu bağlamda hastaneler hem hastaların tedavisinde doğru ilaçları, doğru zamanda ve nitelikli olarak temin etmek zorunda hem de önemli stok maliyetleri ile baş etmek zorundadırlar. İlaç teminini düşük maliyetle, gerektiği kadar ve süreklilik arz edecek şekilde sağlamak hastaneler için son derece önemlidir. Bu nedenle ilaç stok yönetim ve kontrol sistemleri oluşturulmalidir.

Hastaneler stok kontrolünde bazı kriterleri yerine getirmek zorundadır. Hasta açısından hayati öneme sahip ilaçları ellerinde devamlı olarak, daha az önemli ya da muadili olan ilaçları da bulundurma zorunluluklar vardır. Yani hastaneler stok bulundururken fiyat ve tüketim miktarının yanında, ilaçların hayati açıdan ne kadar kritik olduğuna da dikkat etmeleri gerekmektedir. Literatürdeki çalışmaların çoğu bu üç kriteri dikkate alan ABC-VED analizi ile gerçekleştirilmiştir (Wandalkar, Pandit \& Zite, 2013; Pirankar vd., 2014; Singh, Gupta \& Devnani, 2015; Karagöz \& Yıldız, 2015; Fitriana, Satria \& Setiawan, 2018; Savaş, 2018; Yılmaz, 2018; Yiğit \& Yiğit, 2019; Tisinli \& Savaş, 2019; Hussain, Siddharth \& Arya, 2019; Taddele vd., 2019). Bunun yanında ilaçların temini açısından tedarikçilerin güvenilirliği de önemli olduğundan tedarikçi güvenilirliği de bu üç kritere eklenebilir. 
Bu çalışmada, özel bir hastanede ilaçların stok kontrolüne yer verilerek, ilaçların etkin kullanılması ve önem derecelerine göre sıralanması hedeflenmiştir. Çok Kriterli Karar Verme (ÇKKV) yöntemleriyle de oluşturulan sonuçlara göre karşılaştırma yapılarak daha etkili sonuç ortaya konulmaya çalışılmıştır. Çalışmada bu amaca uygun olarak eczane bölümünde kullanılan 958 kalem ilaç verisi yer almaktadır.

Çalışmada ilk olarak, kavramsal çerçeveye yer verilmiş, konu ve yöntemle ilgili literatür incelenmiştir. Uygulama bölümünde, klasik ABC-VED yöntemiyle elde edilen sonuçlar ile tedarikçi kriterinin de içinde bulunduğu AHP ve TOPSIS yöntemleriyle birlikte oluşturulan yeni ABC-VED analiziyle ilgili bulgular elde edilmiştir. Tartışma kısmında iki yöntemin sonuçları ve literatürdeki çalışmaların sonuçları kıyaslanmıştır. Sonuç bölümünde, elde edilen sonuçlara, ilgili yorumlara ve gelecek çalışmalar için önerilere yer verilmiştir.

\section{KAVRAMSAL ÇERÇEVE}

\subsection{Sağlık Hizmetleri}

Sağlık ve hastalık insan yaşamında yer alan önemli kavramlardır. Dünya Sağlık Örgütü (DSÖ)'nün yaptığ 1 tanımlamaya göre sağlık "sadece hastalk ve sakatlı durumunun olmaması değil bedensel, ruhsal ve sosyal yönden de tam bir iyilik durumudur". Bu tanımdan hareketle, sağlığın çok boyutlu bir kavram olduğu ve birbiriyle ilişkili çok sayıda faktörün sağlık durumunu dolaylı veya doğrudan etkilediği söylenebilir (Kavuncubaşı, 2010, s.3).

Toplum tüm kesimlerine yönelik örgütlü sağlık hizmeti anlayışı ve uygulamasının yaygınlaşması İkinci Dünya Savaşı sonlarına rastlamaktadır. Son yıllarda dünyada hizmet sektöründe görülen büyüme ve gelişmeler sağlık hizmetlerini de etkilemektedir (Altuğ \& Özhan, 2017, s. 55). Sağlık hizmetleri kavramı; hastalığın teşhis, hastaların tedavi, bakım ve korunması için kişisel veya kurumsal olarak kamu ya da özel şahısların vermiş olduğu hizmetler şeklinde tanımlanmaktadır (Odabaşı, 2010).

Sağlık hizmeti ihtiyaçları beklenmedik zamanda ortaya çıkarak, karşılanmaktadır. Sağlık hizmetine ihtiyaç duyulduğu vakit yerine verilebilecek başka bir hizmet yoktur. Bu yönüyle sağlık hizmetlerine ihtiyaç duyulduğunda vazgeçmek veya ertelemek mümkün olmayabilir. Bilgi asimetrisi olduğundan bir sağlık hizmetinin nasıl, ne şekilde, hangi oran ve kapsamda tüketileceğini hasta değil doktor belirler. Sağlık hizmetlerinde tüketici davranışı rasyonel değildir. Sağlık hizmetlerinin garantisi olmadığı gibi önceden test edilmesi ve hata kabul etme olasılığı da yoktur. Toplumun tamamını ilgilendirdiği için sağlık hizmetlerinin yokluğu toplumsal sorunlara da yol açabilir. Diğer hizmet sektörlerine kıyasla en soyut hizmet sektörüdür. Bu sektörde alanlarında uzman olan veya olmayan kişiler yer alabilir. Sağlık hizmetlerindeki arz-talep eşitsizliği, hizmetin anında verilememesinin sonuçlarının hayati oluşu ve 
kanuni kısıtlamalar gibi pek çok etken, sağlık sektörünü diğer hizmet sektörlerine göre farklılaştırabilmektedir (Tengilimoğlu, 2012; Odabaşı, 2010).

Hastaneler, hem yüksek maliyetli hem de verdikleri hizmetlerin ötelenemez olmasından dolayı sağlık hizmetlerinde büyük öneme sahiptir. Hastanelerin diğer sektörlere göre bazı ayırt edici özellikleri bulunmaktadır. Hastaneler, karmaşık yapıda açık ve dinamik kuruluşlar olup, iş analizi ve görev tanımlarının yetersizliğinden dolayı matriks organizasyon yapısına sahip kurumsal özellik gösterirler. Hastanelerde uzmanlaşma seviyesi ve meslek grupları sayısının yüksek olması karşılıklı görev bağımlılığı kadar çok sayıda çatışmalara da zemin hazırlar. İnsana dayalı emeğin yüksek olması ve 24 saat hizmet verme zorunluluğu çalışma ortamındaki stres yükünü de arttırmaktadır. Hastane kapsamındaki işlerin acilliği ve ertelenemez oluşu, hatalara karşı duyarlılığın yüksek olmasını ve hızlı karar vermeyi gerektirmektedir (Yarar \& İnce, 2017, ss.1-5).

Hastanelerin genel amaçlarının yanında tıbbi, mali, teknik, idari, araştırma yapma ve geliştirme, eğitim sorumluluğu gibi yerine getirmesi gereken bazı sorumlulukları da bulunmaktadır (Doğanay, 2008, s. 41).

Sağllk sektöründe hizmet veren hastanelerin yönetiminde stok kontrol sistemlerinin incelemesi, söz konusu sağlık hizmeti birimi için en etkin stok kontrol yöntemlerinin saptanması ve malzemelerinin yönetimi en önemli süreçler arasında yer almaktadır. Bu nedenle bu çalışmada öncelikle stok yönetimi konularına yer verilmiştir.

\subsection{Sağlık Hizmetlerinde Stok Yönetimi}

Belirli bir süre atıl durumunda kalan, kullanılmayı ya da satılmayı bekleyen, ekonomik değeri olan, mal ve malzemelere stok adı verilmektedir (Çelikçapa \& Şenol, 2015, s.107). Stok ile envanter kavramları birçok yerde aynı anlama gelmektedir. Fakat aralarında dikkat edilmesi gereken bir nokta vardır. Stokta daha çok mal ve hizmet üretimi ve satışı için gereken malzemeler yani fiziksel varlıklar kastedilmektedir. Envanterde ise anlam daha genişlemiş olup, stokların yanı sıra makine gibi demirbaş malzemeleri de kapsamakta ve çoğunlukla parasal olarak ifade edilmektedir (Kobu, 2010, s.325; Tanyaş \& Baskak, 2013, s.124). Sağllk sektöründe stok, verilecek hizmetin kesintiye uğramadan sürdürülmesini sağlamak amaciyla bulundurulan her türlü mal ve malzemelere denilmektedir (Akman, 2003, s. 16).

Yapılan çalışmalara göre sağlık sektöründe stok maliyetleri \%10 ila \%18 arasında değişmektedir (Rachmania \& Basri, 2013). Hastane özelinde bakıldığında, hastane giderlerinin yaklaşık \%30-40’ının stoklara yapılan harcamalardan oluştuğu belirtilmektedir (Huarng, 1998, s. 71). Bu nedenle stoklar, sağllk sektöründe hizmet veren hastaneler için en önemli girdi kaynağı olarak görülmektedir (Tengilimoğlu \& Yiğit, 2017, s.162). Stoklara, sağlık sektöründe hizmet veren hastanelerin verimliliğini ve rekabet gücünü arttırdığ 1 için önem verilmektedir (Filiz, 2008, s. 149). Stoklar, talep dalgalarına cevap verebilme ve tedarikte yaşanan 
sorunlarda tampon görevi görme gibi fonksiyonlara sahiptir (Küçük, 2017, s. 23). Hastanelerin stok yönetimini en düşük maliyetle yürütebilmesi; talebe dayanan stokların en az hatayla tahmini, faaliyetine devam imkanı veren stok miktarının tespiti, siparişlerin uygun miktarda ve zamanda verilmesine bağlıdır (Türk \& Şeker, 2011, s.715).

Stok yönetimi, stokların maliyetlerinin sınıflandırılmasına ve tahmin edilmesine yardımcı olmaktadır (Tekin, 2003, s. 3). Hastanelerde bulunması gereken stokların büyük bir kısmı kullanım süresi ve yüksek maliyeti nedeniyle kısıtlanmaktadır. Böylelikle hastaneler çok fazla stok bulundurmayıp yedi ile on gün arasında günlük stokla çalışmayı yeterli görmektedir. ABD'deki hastanelerde yapılan araştırmalara göre de hastanelerin, bir haftalık stokla hizmet verdikleri görülmektedir (Ağırbaş, 2013, s.182). Stokların yetersiz oluşu zaman ve iş kayıplarına, fazla oluşu da stok giderlerinin artmasına ve sermayenin büyük bir kısmının durağan konumda kalmasına neden olmaktadır (Tengilimoğlu \& Yiğit, 2017, s. 163). Stoklar, gereğinden fazla alanı kapladığında daha çok depo çalışanına ihtiyaç duyulmakta, depo ve sigorta masraflarının da yükselmesine neden olmaktadır. Stoklar bozulma, eskime, yıpranma gibi riskleri olduğu için değerinde ve kalitesinde bir düşüş de yaşanabilir. $\mathrm{Bu}$ durum stokların değerini önemli derecede etkileyeceği gibi stokları ölü hale de getirebilmektedir. Bu gibi risk ve maliyet unsurları stok yönetiminin sektörlerde neden önemli olduğunu göstermektedir (Başyazıc1, 2010, s. 8).

Sağlık sektöründe hizmet veren hastanelerin stok sınıflandırılması tıbbi stoklar (İlaçlar, laboratuvar, tıbbi sarf, radyoaktif, tıbbi gazlar ve diğer tıbbi sarf malzemeleri) ve diğer stoklar (yiyecek, temizlik, büro, ısıtma, akaryakıt ve yağlar, teknik bakım ve onarım malzemeleri) olmak üzere iki grupta yapılmaktadır (Ağırbaş, 2013, s.103).

Hastaneler hizmet türlerine, stok politikalarına, mali durumlarına ve diğer faktörlere bağlı olarak bir stok kontrol yöntemi geliştirmek durumundadırlar. Stoklardaki malın talebinin bağımlı ya da bağımsız oluşu, stokları planlamak ve denetlemek için kullanılabilecek yöntemi belirleyen önemli bir özelliktir. Fakat bu özelliğe bakılmaksızın stok kontrolünde en çok kullanılan yöntemlerin Gözle Kontrol Yöntemi, Çift Kutu Yöntemi, Sabit Sipariş Periyodu Yöntemi, Sabit Sipariş Miktarı Yöntemi, ABC (Always Better Control) Yöntemi, VED (Vital, Essential, Desirable) Yöntemi, ABC-VED Matris Yöntemi, Ekonomik Sipariş Miktarı Yöntemi ve Tam Zamanında Üretim (JIT) yöntemi olduğu görülmektedir.

Bağımsız stok kalemleri için kullanılan yöntemler genel olarak irdelendiğinde cevap aranan soru ne kadar sipariş verileceği ve ne zaman sipariş verileceğidir. Sürekli gözden geçirme sistemi veya $Q$ sistemi olarak da anılan sabit sipariş miktarı sisteminde her seferinde verilecek sipariş miktarı $(\mathrm{Q})$ sabit olmakla birlikte, iki sipariş verilişi arasındaki süre talebin ve tedarik süresinin sabit olup olmamasına göre farklılaşabilmektedir. Stok düzeyi belirli bir seviyeye düştüğünde daha önceden belirlenen sabit bir miktar kadar sipariş verilmektedir. Bunun için eldeki stok düzeyinin sürekli olarak gözden geçirilmesi gerekmektedir. P sistemi 
veya periyodik gözden geçirme sistemi olarak da anılan sabit sipariş periyodu sisteminde iki sipariş verme arasında geçen süre sabit olup her siparişte sipariş verilecek miktar değişebilmektedir. Bu sistemde stok düzeyinin sürekli olarak gözden geçirilmesine gerek yoktur, belirli aralıklarla gözden geçirilip gözden geçirildiği anda eldeki stok düzeyine göre sipariş verilmektedir (Krajewski, Ritzman \& Malhotra, 2013, ss.340-345).

\subsubsection{ABC (Always Better Control) Yöntemi}

ABC şeklinde kısaltılmış, aslında "Always Better Control" isminden gelen ve Türkçe'de "Daima Daha İyi Kontrol" anlamını taşıyan bu yöntem, stokları oluşturan maddeler arasındaki karışımın saptanmasına dayanmakta ve stok kontrolünde kullanılan en eski yöntem olarak bilinmektedir. Analizin esasını, stok karışımını oluşturan ürünleri fiyat ve tüketim miktarı çarpımından oluşan yıllık tüketim değerine göre bir sıraya konulması oluşturmaktadır (Demir \& Gümüssoğlu, 2009, s.531). Özellikle büyük stoklara sahip sektörler bu yöntemi kullanmaktadır. Stok kalemlerinin toplamları içinde kümülatif yüzdelerine göre sınıflandırılmasından oluşan bu stok kontrol yöntemine göre stoklar üç grupta toplanmaktadır (Kobu, 2010, s.335):

- A Grubu: Bu gruptaki stok kalemleri, toplam stok çeşit sayısının \%15-20’sini, toplam stok değerlerinin de \%75-80'nini oluşturmaktadır.

- B Grubu: Bu gruptaki stok kalemleri, toplam stok çeşit sayısının \%30-40'ını, toplam stok değerinin de \%10-15’ini oluşturmaktadır.

- C Grubu: Son olarak bu gruptaki stok kalemleri ise, toplam stok çeşit sayısının \%4050’sini, toplam stok değerinin de \%5-10’unu oluşturmaktadır.

$\mathrm{ABC}$ analizinin en önemli amacı, stok tüketim değeri en yüksek olan A grubu stoklardan daha az bulundurup kontrolünü sıkılaştırmaktır. Özellikle ilaçlar için yaygın olarak kullanılan yöntemlerdendir (Holmgren \& Wentz, 1982, s. 128). Kisacası bu stok modeli, stokları kümülatif değerleri bakımından sınıflandırmayı sağlayarak, stoklara büyük paralar ayrılmasını veya bağlanmasını engellemektedir (Küçük, 2017, s. 89).

\subsubsection{VED (Vital, Essential, Desirable) Yöntemi}

İngilizce'de "Vital, Essential, Desirable" olarak bilinen kısaca baş harflerinden oluşan Türkçe'de de "Hayati, Temel, İstenilen" anlamına gelen VED yöntemi, daha çok hastanelerde ilaç ve tıbbi malzemelerin kontrolünde kullanılmaktadır. Bu yöntem ilaç ve malzemeleri insan hayatı açısından taşıdığı değere göre üç gruba ayırmaktadır. Bu gruplandırma aşağıdaki gibi yapılmaktadır (Tengilimoğlu \& Yiğit, 2017, s. 177-178):

- V Grubu (Birinci Grup) Malzeme ve İlaçlar: Hayati önem taşıyan ve sağlık sektöründe hizmet veren kurumlarda mutlaka bulunması gereken malzemelerdir. 
- $\quad$ E Grubu (İkinci Grup) Malzeme ve İlaçlar: Hayati açıdan önemli olmasına rağmen alternatifi bulunabilen malzemelerdir.

- $\quad$ D Grubu (Üçüncü Grup) Malzeme ve İlaçlar: Hayati açıdan çok da önemi bulunmayan ve bulundurulması isteğe bağlı olan malzemelerdir. Bu gruptaki malzemelerin hastanelerin vermiş olduğu hizmetler üzerinde doğrudan etkisi bulunmamaktadir.

Özellikle V ve E grubu malzeme ve ilaçların her an elinde olacak şekilde hastane stoklarında bulunması ve emniyet stokunun yüksek tutulması gerekmektedir. Hastanelerde malzeme veya ilaç stok kontrolünde $A B C$ ve $V E D$ yöntemlerinin bir arada kullanılmasının mümkün olduğu görülmektedir.

\subsubsection{ABC-VED Matris Yöntemi}

ABC-VED matris yöntemi, hem malzemenin maliyeti, hem de insan hayatı açısından taşıdığı önem derecesine göre birleştirilerek geliştirilen yeni bir stok kontrol yöntemidir. K1sacası bu yöntemde, $A B C$ ve VED analizlerindeki gruplar birbirleriyle $(A+V=A V)$ şeklinde birleştirilmektedir. Böylece AV grubunda hem A grubundaki hem de V grubundaki stoklar yer almaktadır. Ortaya çıkan kombinasyonlar üç kategoride sınıflandırılmaktadır. Bu sınıflandırmalar aşağıda belirtilmiştir (Nigah, Devnani \& Gupta, 2010, p. 203):

- $\quad$ 1. Kategori (AV, AE, AD, BV ve CV): Bu kategoride yer alan ilaçlar, hem maliyet açısından yüksek hem de hasta açısından hayati öneme sahip ilaçlardır. Birinci kategoride yer alan ilaçların yakından izlenmesi ve sık sık kontrollerinin yapılması gerekmektedir.

- 2. Kategori (BE, CE ve ED): Bu kategoride yer alan ilaçlar, hem maliyet hem de hasta açısından orta derece öneme sahip olan ilaçlardır. Bu grupta yer alan ilaçlar için normal kontrollerin yapılması yeterli görülmektedir.

- $\quad$ 3. Kategori (CD): Bu kategoride yer alan ilaçlar ise hem maliyet açısından hem de hayati önem açısından değeri yüksek olmayan malzemelerden oluşmaktadır. Stok kontrolleri bakımından sıklıkla kontrol edilmeyi gerektirmeyen ilaçların oluşturduğu grup olarak görülmektedir.

\subsubsection{Analitik Hiyerarşi Süreci (AHP) Yöntemi}

Analytic Hierarchy Process olarak bilinen fakat Türkçe’ye Analitik Hiyerarşi Süreci olarak geçen ve kısaltılmış hali AHP olan bu yöntem aynı zamanda çok kriterli karar verme yöntemleri arasında yer almaktadır. 1968 yılında Myers ve Alpert tarafından geliştirilen bu yöntem, 1970'li yıllarda Thomas Saaty tarafından bir model olarak, çok kriterli karar 
verme problemlerinin çözümünde uygulanabilir hale getirilmiştir (Mutlu \& Sarı, 2017, s.183).

AHP yöntemi, kriterleri ikili bir şekilde karşılaştırmakta ve ikili karşılaştırmaların tutarlı olup olmadığını ölçmektedir (Tayyar, Akcanlı, Genç \& Erem, 2014, s.21). AHP yöntemi, altındaki birçok alternatifin arasından seçim yaparken, çok sayıdaki karar vericilerin de seçime katkıda bulunmasına imkan vermektedir. Bu durumda başarılı ve gerçekçi sonuçlara ulaşılabilmesi için konularında uzman kişilerin tercih edilmesi önem arz etmektedir. Kişilerin ikili karşılaştırmalardaki bilgilerinin tutarlılığına dayanarak AHP yöntemi, başarılı sonuçlar vermektedir (Şahin, 2007, s. 47).

AHP yönteminde bir probleme ait kriter ve alternatiflerin ağırlıkları sıralanarak önem dereceleri belirlenmeye çalışılmaktadır. AHP yöntemi bir tek kişiden ziyade bir uzman grubun kararlarını ve karşılaştırmalarını girdi olarak alabilmektedir (Kuruüzüm \& Atsan, 2001). Gruptaki üyelerin her birisi tüm kriterle alakalı olarak yargıda bulunacağından, sürecin sonunda uzlaşma gerekecektir. Böyle durumlarda uzlaşmaya varılacağ gibi geometrik ortalama ile yargıları birleştirme yoluna da gidilebilir (Ömürbek \&Tunca, 2013, s.57).

ÇKKV karar verme yöntemlerinin temelini oluşturan ve çoğu yöntemde kriter veya alternatiflerin önem derecelerinin belirlenmesinde kullanılan AHP yönteminin çözümünde bazı adımlar izlenmektedir. Bu adımlar aşağıda kısaca verilmektedir (Yıldırım \& Önder, 2015, s.23):

- Karar verme probleminin tanımlanması ve amacinın belirlenmesi,

- Karar kriterlerinin belirlenmesi,

- Muhtemel karar alternatiflerinin belirlenmesi,

- Karar probleminin hiyerarşik yapısının oluşturulması,

- Hiyerarşinin her seviyesi için kriterlerin ikili karşılaştırılması ve öz vektörlerden yararlanarak kriterlerinin önem derecelerinin belirlenmesi,

- Kriterlere göre alternatiflerin ikili karşılaştırılması ve önceliklerinin hesaplanması,

- Uyum oranının hesaplanması,

- Göreceli öncelik değerlerine göre alternatiflerin sıralanması ve en yüksek öncelik değerine sahip olan alternatifin belirlenmesi,

- Duyarlılık analizinin yapılmasıdır.

Hesaplanan tutarlılık oranının 0,1'den küçük olması iyi (tutarlı/ duyarlı/ uyum sınırları içerisinde) olarak adlandırılmaktadır. Aksi takdirde uyum oranları (duyarlılık analizi) yeniden gözden geçirilmektedir (Yıldırım \& Önder, 2015, s.42). 


\subsubsection{Technique for Order Preference by Similarity to Ideal Solution (TOPSIS) Yöntemi}

Karar verme sürecinde kullanılan yöntemlerden birisi olan TOPSIS, “Technique for Order Preference by Similarity to Ideal Solution" kelimelerinin baş harflerinden oluşmaktadır (Hwang \& Yoon, 1981). TOPSIS, alternatifler arasından en iyi seçimin yapılmasına imkan tanıyan bir yöntemdir.

Hwang \& Yoon (1981)'un çalışmaları referans gösterilerek ortaya konulan TOPSIS yöntemi ÇKKV yöntemlerinden birisidir (Demireli, 2010, s.105). Bu yöntemin temelinde karar noktalarının pozitif ve negatif ideal çözümden uzaklıklarının belirlenmesi ve karar noktaları arasında bir sıralama yapılması yatmaktadır (Chen, 2000, s. 2). Pozitif ideal çözüm, tercih edilmesi gereken noktayı yansıtırken; negatif ideal çözüm ise tercihten kaçınılması gereken noktayı ifade etmektedir. TOPSIS yönteminde, ideal çözüm uygulanamaz veya ulaşılamaz olursa, o zaman ideal çözüme en yakın noktanın seçilmesi gerekmektedir. Pozitif-ideal, çözüme en yakın çözüm olurken, negatif-ideal, çözüme en uzaktır. Yani yöntemde pozitif ideal çözüm “1” iken, negatif ideal çözüm “0” ile temsil edilmektedir. Bu yöntemde, karar noktalarının sadece "0" ile " 1 ” arasında değer alabilir. Yöntem gereği, pozitif ideal çözüm ve negatif ideal çözüm değerlerinden hareketle her bir karar noktasına ait yakınlık katsayısı hesaplanmakta ve karar noktaları arasında sıralama yapılmaktadır (Özgüven, 2011; Özdemir \& Seçme, 2009).

\section{LITERATÜR ARAŞTIRMASI}

Flores \& Whybark (1987), ABC analizi ile ilgili yaptığı araştırma literatürdeki ilk çalışmadır. Bu çalışmadan etkilenen (Chen vd., 2008), tedarik süresi ve stokta bulundurulan malzemelerin kritikliği gibi ilave kriterler ekleyerek uygulamada çok kriterli ABC analizini yapmışlardır. Ernst \& Cohen (1990), araştırmalarında istatistiksel kümelemeye dayanan bir yöntem bulmuşlardır. Fakat bu yöntemi, stok kontrol sistemini etkilediği ve orta kademe yöneticilere de çok karmaşık geleceğini düşündükleri için önermemişlerdir.

AHP yöntemi, birçok kriteri birleştirerek büyük hesaplamalarda ve ölçüm sistemlerinde kullanım kolaylığı sunarak öne çıkmaktadır. Bu nedenle de literatüre bakıldığında ABC analiziyle birlikte AHP yönteminin de kullanıldığı görülmektedir. Bu yöntem sübjektiflik içerdiğinden bazı dezavantajları olduğu belirtilmektedir (Chu, Liang \& Liao, 2008; Partovi \& Anandarajan, 2002; Flores, Olson \& Dorai, 1992). Çakır \& Canbolat (2008), çok kriterli stok sınıflandırma problemini çözümlemek için bulanık AHP yöntemini önermiştir. Güvenir \& Erel (1998) ise çok kriterli sınıflandırma için AHP tekniği ve genetik algoritmayı birlikte kullanarak yeni bir yöntem sunmuştur. Partovi \& Anandarajan (2002), stok kalemlerinin ABC yöntemi ile sınıflandırılması için iki öğrenme metodu olan geriye yayılım ve genetik algoritmadan yararlanan yapay bir sinir ağı önermişlerdir. Ramanathan (2006) ise çok kriterli stok 
sınıflandırması problemi için veri zarflama analizine benzeyen basit ağırlıklı doğrusal optimizasyon modelini önermiştir. Zhou \& Fan (2007), çok kriterli ABC stok sınıflandırması için bazı dengeleme özelliklerini de dahil ederek Ramanathan’ın modelinin genişletilmiş halini sunmuş ve elde ettikleri sınıflandırma sonuçlarını bulanık sınıflandırıcıların sonuçları ile karşılaştırmışlardır. Sonuç olarak da önerdikleri yöntemin diğerlerinden daha üstün olduğunu ortaya koymuşlardır. Chu ve diğerleri (2008) ise ABC analizi ve bulanık sınıflandırmayı entegre ederek yeni bir stok kontrol yöntemi önermişlerdir.

Sağlık sektöründe $A B C$ analizi yukarıdaki yöntemlerden ziyade VED analiziyle birlikte kullanılmıştır. ABC-VED analizinin kullanıldığı pek çok çalışma bulunmaktadır. Son yıllarda yapilan çalışmalara örnek vermek gerekirse; Savaş (2018), ameliyathane bölümünde stok kontrolü için, Yllmaz (2018), bir hastanenin ilaç stoklarının kontrolü için, Yiğit \& Yiğit (2019), hastanelerde tıbbi malzeme stoklarının kontrolü için, Tisinli \& Savaş (2019), ameliyat odalarında malzemelerin stok kontrolü için ABC VED yöntemini kullanmışlardır. Yabancı literatür incelendiğinde ise $\mathrm{ABC}$-VED analizinin uzun yıllardır pek çok ülkede yaygın olarak kullanıldığı görülmektedir. Son yıllarda farklı ülkelerde yapılan çalışmalara örnekler vermek gerekirse, Fitriana vd. (2018), Endonezya'da bir veteriner fakültesi hastanesinde stok kontrolü için, Taddele vd. (2019), Etiyopya'da bir sağlık kurumunun eczanesindeki ilaçların stok kontrolü için, Hussain vd. (2019), Hindistan’da bir sağlık kurumunun stok kontrolü için ABC-VED analizini kullanmışlardır.

TOPSIS, sunduğu avantajlardan ötürü işletme yönetimi ve gündelik yaşamla ilgili ÇKKV problemlerinin çözümünde araştırmacılar tarafından sıkça kullanılmaktadır (Demireli, 2010, s. 104; Yıldırım \& Önder, 2015, s. 134). Birçok yazar çalışmalarında TOPSIS yöntemini farklı amaçlar doğrultusunda kullanmışlardır. Huang (2016), hasta portföy analizi yapabilmek Lau vd. (2016), müşteri ilişkileri yönetimini geliştirebilmek ve işletme için en karlı müşteriyi belirleyebilmek, Mehralian vd. (2016), toplam kalite yönetimini etkileyen kritik başarı faktörlerini tespit edebilmek, Kumar, Datta ve Mahapatra (2016), üretim sistemlerinin bakımı önündeki engelleri belirleyebilmek ve sıralama yapabilmek, Parsaei, Keramati, Zorriassatine ve Feylizadeh (2012), sipariş kabul sürecini inceleyebilmek, Liu ve Li (2015), üniversite eğitim kalitesini değerlendirebilmek, Ghosh (2011), fakülte performanslarını analiz edebilmek, Song ve Zheng (2015), yüksekokullardaki eğitim kalitesinde inceleme yapabilmek, Wang, Chiu ve Wu (2015), en iyi web hizmetlerini tespit edebilmek için TOPSIS yöntemini kullanmıştır. Behzadian vd.(2012), TOPSIS yönteminin çoğunlukla tedarik zinciri ve lojistik yönetimi ile tasarım, mühendislik ve imalat sistemleriyle alakalı olarak kullanıldığını ifade etmişlerdir. Houska (2012), ülkelerin ekonomik performanslarını değerlendirebilmek, Özgüven (2011), perakendecilerin performanslarının değerlendirebilmek, Monavvarian vd. (2011), bilgi yönetim stratejisini belirlemek, Jadidi, Firouzi ve Bagliery (2010) ise tedarikçi seçimi yapabilmek amacıyla TOPSIS yöntemini tercih etmiştir. Bhattacharya, Sarkar ve Mukherjee (2007), ABC analizi için TOPSIS yöntemini kullanmışlardır. 
Literatür araştırmasında da görüldüğü üzere stok sınıflandırması ve başka amaçlar için ABC, VED, ABC-VED Matris yöntemleriyle birlikte ayrı ayrı AHP, TOPSIS ve diğer karar verme yöntemlerinin kullanıldığı görülmektedir. Fakat yerli ve yabancı hiçbir çalışmada ABC, VED ile birlikte AHP ve TOPSİS yöntemlerini bir arada kullanılmadığı görülmektedir. Yani farklı sebepler doğrultusunda bazı yöntemler bir arada kullanılmış ama sağlık sektöründe stok kontrolü için bu yöntemleri bir arada kullanan çalışmaların mevcut olmadığ görülmüştür.

\section{SAĞLIK SEKTÖRÜNDE ÇOK KRITERLI STOK SINIFLANDIRMA UYGULAMASI}

\subsection{Araştırmanın Konusu ve Amacı}

Sağlık sektöründe hizmet veren hastanelerin, hizmetlerini kesintisiz olarak devam ettirebilmeleri için stok yönetimlerine dikkat etmeleri gerekmektedir. Bu durum hem sektörde stok ile ilgili kararların sonuçlarının hayati önem taşımasından hem de sektördeki stok maliyetlerinin yüksek olmasından kaynaklanmaktadır. Dolayısıyla hem maliyet açısından hem de insan sağlığı açısından kritik öneme sahip olan hastaneler, stoklarındaki ilaçların takibini çok iyi yapmak durumundadırlar.

Araştırmanın konusu sağlık sektöründe stok sınıflandırması gerçekleştirmek ve ÇKKV yöntemlerine dayalı alternatif bir sınıflandırma sistemi önermektir. Araştırmanın iki temel amacı bulunmaktadır. Araştırmanın ilk amacı literatürde kullanılan ABC-VED matris analizi yöntemiyle bir hastanenin stoklarındaki ilaçların fiyat, talep, kritiklik kriterlerine göre s1nıflandırılarak elde edilen sonuçların literatürle karşılaştırılmasıdır İlk amaç doğrultusunda yapılan analizin sonuçlarına göre yapılacak stok sınıflandırması daha önce böyle bir sınıflandırmaya gitmemiş olan hastane için stok kontrol politikası oluşturma aracı olarak pratik fayda sağlayacaktır. Çalışmanın ikinci amacı ise, ABC-VED analizinde yer almayan tedarikçi güvenilirliği kriterini de diğer üç kriter arasına ekleyerek, dört kriterli AHP ve TOPSIS yöntemlerinin uygulandığı sağlık sektörü stok kontrolünde kullanılabilecek yeni bir sınıflandırma elde etmektir. Elde edilmiş iki ABC-VED sınıflandırma sonuçları ile literatürdeki benzer çalışmalar karşılaştırılarak aralarındaki farklılıkları gözlemlemek de çalışmanın diğer amacidır.

\subsection{Araştırma Verilerinin Toplanması}

Çalışmada Trakya bölgesinde hizmet veren özel bir hastanenin stok verileri kullanılmıştır. Bu özel hastanenin stoklarında birçok ilaç ve malzeme bulunmaktadır. Maliyeti ve hastaların hayatına etkisi bakımından düşünüldüğünde stoklar arasında bulunan eczane bölümündeki 958 çeşit ilaç verisi, bu çalışmada kullanılmak üzere tercih edilmiştir. 2017 yılının 
ilaçlarına ait yıllık tüketim miktarları ve fiyatları hastanenin izni doğrultusunda elde edilmiştir. Analizler MS Excel'de yapılmıştır.

$\mathrm{ABC}$ analizi için gerekli olan ilaçların stok miktarı ve maliyetleri hastanenin otomasyon kayıtlarından elde edilmiştir. VED yöntemi için gereken ilaçların kritikliği, AHP yöntemi için gereken karşılaştırma ve TOPSIS yöntemi için gereken tedarikçilerin güvenilirliği bilgileri için uzman kişilerle (doktorlar, başhemşire, hastane yöneticileri, satın alma sorumlusu, depo/ eczane çalışanları) yüz yüze görüssmeler yapılmış ve gerekli olan bilgiler toplanmıştır.

\subsection{Araştırmanın Yöntemleri ve Elde Edilen Bulgular}

Araştırmada ilk olarak, talep ve fiyattan oluşan yıllık tüketim değeri açısından sınıflandırma yapan $\mathrm{ABC}$ analiziyle bir sınıflandırma yapılmıştır. $\mathrm{ABC}$ analizinde ilaçlar yıllık tüketim değerine göre büyükten küçüğe doğru bir listede sıralanmıştır. ABC yöntemindeki bu sırlamada en üstte yer alan ilaçlar yıllık tüketim değerine göre en yüksek ve en sıkı kontrol edilmesi gereken ilaçlardır. Bu listede yıllık kümülatif tüketim değerinin yaklaşık \%80'ine kadarı oluşturan ilaçlar A grubu, yıllık kümülatif tüketim değerinin sonraki \%15'ini oluşturan ilaçlar B grubu, son \%5’ini oluşturan ilaçlar ise C grubu olarak sınıflandırılmıştır. Daha sonra hastane ve hastalar için önemli olan ilaçların sınıflandırmasının yapılabilmesi için VED yöntemi kullanılmıştır. Bu iki yöntemin birleştirilmesiyle elde edilen ABC-VED matris analiziyle, hem ilaçların yıllık tüketim değeri hem de insan hayatı açısından taşıdığı önem derecesine göre sınıflandırma yapılmıştır.

Tedarikçi güvenilirliği kriterinin kullanılabilmesi için yeni bir yöntem oluşturulmuştur. $\mathrm{Bu}$ yöntemde talep yani yıllık tüketim, fiyat ve tedarikçi güvenilirliği kriterleri birlikte kullanılmıştır. Bu kriterler öncelikle AHP yöntemiyle ağırlıklandırılmıştır. Sonrasında TOPSIS yöntemiyle her stok kaleminin ağırlığı ve her üç kriterden aldıkları skorlar kullanılarak ilaçların sıralaması gerçekleştirilmiştir. Bu sıralama ABC analizinde yıllık tüketim değeri sıralamasına benzer bir sıralama olarak görülebilir. Aradaki fark, $A B C$ analizindeki sıralamada yıllık tüketim miktarı ve fiyat kriterleri ağırlıklandırılmadan kullanılırken, yeni sıralamada yıllık tüketim miktarı, fiyat ve tedarikçi güvenilirliği kriterlerinin ağırlıklandırılarak kullanılmasıdır. ABC analizinde yıllık tüketim değerleri büyükten küçüğe sıralanırken burada TOPSIS sonucu elde edilen $C^{\star} i$ değerlerine göre ilaçlar büyükten küçüğe sıralanmıştır. $\mathrm{Bu}$ yeni sıralamada ilaçların aynen ilk yapılan $\mathrm{ABC}$ analizinde olduğu gibi kümülatif tüketim değerine bakılarak, kümülatif tüketim değeri \%80’e kadar olanlar A grubunda, \%81-\%95 arası B grubunda, \%96 ve üstü de C grubunda yer alacak şekilde yeni A, B, C sinıfları elde edilmiştir. Elde edilen A, B, C grupları yeni A,B,C grupları olarak adlandırılmıştır. Yeni A, B, $\mathrm{C}$ grupları ile VED analizi birleştirilerek yeni ABC-VED matrisi elde edilmiştir. 


\subsubsection{ABC-VED Yöntemiyle Sınıflandırma}

ABC analizinde hastanenin 2017 yllında tüketmiş olduğu 958 çeşit ilacın yıllık tüketim miktarı ve ilaç fiyatları (TL) elde edilmiştir. Her ilaç için bu iki değerin çarpımı ile yıllık tüketim değeri (TL) hesaplanmıştır. İlaçlar yıllık tüketim değeri bazında büyükten küçüğe doğru sıralanmış ve kümülatif yıllık tüketim değerleri yüzdelik olarak hesaplanmıştır. A grubu ilaçların toplam ilaç miktarındaki oranı \%10 iken yıllık tüketim değeri içindeki oranı \%80, B grubu ilaçların miktar oranı \%13 iken yıllık tüketim değeri içindeki oranı \%15, C grubu ilaçların miktarındaki oran $\% 77$ iken yıllık tüketim değeri içindeki oranı $\% 5$ olarak elde edilmiştir (Tablo 1).

Tablo 1: ABC Analiz Sonuçları

\begin{tabular}{|c|c|c|c|c|}
\hline Gruplar & İlaç Miktarı (\%) & İlaç Miktarı & Yıllık Tüketim Değeri (\%) & Ylllık Tüketim Değeri (TL) \\
\hline A & 10 & 91 & 80 & 1008793,44 \\
\hline B & 13 & 128 & 15 & 190245,46 \\
\hline C & 77 & 739 & 5 & 63559,57 \\
\hline TOPLAM & $\mathbf{1 0 0}$ & $\mathbf{9 5 8}$ & $\mathbf{1 0 0}$ & $\mathbf{1 2 6 2 5 9 8 , 4 7}$ \\
\hline
\end{tabular}

Hastanede görevli uzmanlardan (yöneticilerden, doktorlardan hemşirelerden, satın alma ve eczanede çalışan uzman kişilerden) alınan bilgiler neticesinde kritiklik açısından her bir ilaç değerlendirilmiş ve $\mathrm{V}, \mathrm{E}, \mathrm{D}$ şeklinde gruplanmıştır. Bu kategorilerde yer alan ilaçların adet ve \% olarak miktarları, yıllık tüketim değerleri (\%) ve her kategorideki ilaçların toplam maliyeti Tablo 2'de görülmektedir.

Tablo 2: VED Analiz Sonuçları

\begin{tabular}{|c|c|c|c|c|}
\hline Gruplar & İlaç Miktarı (\%) & İlaç Miktarı & Ylllık Tüketim Değeri (\%) & Yıllık Tüketim Değeri (TL) \\
\hline V & 29 & 283 & 44 & 555809,86 \\
\hline E & 32 & 304 & 32 & 397699,94 \\
\hline D & 39 & 371 & 24 & 309088,67 \\
\hline TOPLAM & $\mathbf{1 0 0}$ & $\mathbf{9 5 8}$ & $\mathbf{1 0 0}$ & $\mathbf{1 2 6 2 5 9 8 , 4 7}$ \\
\hline
\end{tabular}

Tablo 2'de görüldüğü üzere 958 çeşit ilaçtan 283 çeşit ilaç V grubunda yer almaktadır. 304 çeşit ilaç ise E grubunu oluşturmaktadır. Geriye kalan 371 çeşit ilacın D grubunda olduğu tespit edilmiştir.

ABC-VED matris analizinde hem A, B, C hem de V, E, D gruplarının kombinasyonları ile yeni gruplar oluşturulmuştur (Tablo 3). Bu gruplar birleştirilerek, birinci, ikinci ve üçüncü şeklinde kategori sınıflandırılma yapılmıştır (Tablo 4). Örneğin bir ilaç $\mathrm{ABC}$ analizinde $\mathrm{A}$ ise veya $\mathrm{VED}$ analizinde $\mathrm{V}$ ise birinci kategoride yer almaktadır. 
Tablo 3: Detaylı ABC-VED Matris Sonuçları

\begin{tabular}{|c|c|c|c|c|}
\hline Gruplar & İlaç Miktarı (\%) & İlaç Miktarı & Ylllık Tüketim Değeri (\%) & Yıllık Tüketim Değeri (TL) \\
\hline A+V & 4,28 & 41 & 34,68 & 437896,09 \\
\hline A+E & 3,34 & 32 & 24,68 & 311667,32 \\
\hline A+D & 1,88 & 18 & 20,53 & 259230,03 \\
\hline B+V & 5,95 & 57 & 7,68 & 20974,14 \\
\hline C+V & 19,31 & 185 & 1,66 & 64612,36 \\
\hline B+E & 4,70 & 45 & 5,12 & 28658,96 \\
\hline B+D & 2,71 & 26 & 2,27 & 21420,26 \\
\hline C+E & 23,70 & 227 & 1,70 & $\mathbf{1 2 6 2 5 9 8 , 4 7}$ \\
\hline C+D & 34,13 & 327 & 1,68 & \\
\hline TOPLAM & $\mathbf{1 0 0}$ & $\mathbf{9 5 8}$ & $\mathbf{1 0 0}$ & \\
\hline
\end{tabular}

Tablo 4: Kategori Bazında ABC-VED Matris Sonuçları

\begin{tabular}{|c|c|c|c|c|c|}
\hline Kategori & Çaprazlanan Gruplar & $\begin{array}{c}\text { İlaç Miktarı } \\
(\%)\end{array}$ & İlaç Miktarı & $\begin{array}{c}\text { Yıllık Tüketim } \\
\text { Değeri (\%) }\end{array}$ & $\begin{array}{c}\text { Yıllık Tüketim } \\
\text { Değeri (TL) }\end{array}$ \\
\hline I & AV+AE+AD+BV+CV & 35 & 333 & 89 & 1126707,21 \\
\hline II & $\mathrm{BE}+\mathrm{BD}+\mathrm{CE}$ & 31 & 298 & 9 & 114691,58 \\
\hline III & $\mathrm{CD}$ & 34 & 327 & 2 & 21199,68 \\
\hline TOPLAM & & 100 & 958 & 100 & 1262598,47 \\
\hline
\end{tabular}

ABC-VED matrisi sonuç tablosuna bakıldığında $\mathrm{AV}, \mathrm{AE}, \mathrm{AD}, \mathrm{BV}$ ve $\mathrm{CV}$ grupları birinci kategoriyi oluşturmaktadır ve 333 çeşit ilacın da bu kategoride yer aldığı görülmüştür. BE, BD ve CE grubunun oluşturduğu ikinci kategoride ise 298 çeşit ilaç yer almaktadır. Son olarak CD grubundan oluşan üçüncü kategoride ise 327 çeşit ilaç yer almaktadır. Gruplara ait maliyetler ve oranlar bu tabloda detaylı olarak verilmiştir.

\subsubsection{AHP Yöntemi ile Ağırlıkların Belirlenmesi}

Çalışmada talep, ilaç fiyatı ve ilacın kritikliğinin yanında tedarikçi güvenilirliğinin de stok kontrolü sınıflandırmasında önemli olduğu düşünüldügünden, dördüncü kriter olarak eklenmiştir. VED analizindeki kritiklik ölçütleri, AHP ve TOPSIS sonrasında elde edilen yeni ABC sınıflamasıyla birleştirmede kullanıldığından VED sınıflaması için kullanılan kritiklik faktörü dışarda bırakılarak talep, fiyat ve tedarikçi güvenilirliği kriterlerinin ağırlıkları AHP yöntemiyle belirlenmiştir. AHP yöntemi için Saaty’nin 1-9 ölçeği kullanılarak anket formu oluşturulmuştur. Oluşturulan anket formu hastanede çalışan, altı uzman kişi tarafından doldurulmuş, analiz Excel programıyla gerçekleştirilmiştir. Elde edilen ikili karşılaştırma matrisi (İKM) sonuçları Tablo 5'de görülmektedir. 
Tablo 5: Anket Verilerine Göre AHP Analiz Sonuçları

\begin{tabular}{|c|c|c|c|c|c|c|}
\hline \multicolumn{7}{|c|}{ Uzmanların Anket Sonuçları } \\
\hline 1. Uzman & Fiyat & Talep & $\begin{array}{c}\text { Tedarikçi } \\
\text { Güvenirliği }\end{array}$ & & & \multirow{5}{*}{$\mathrm{n}=3$ için } \\
\hline Fiyat & 1,00 & 3,00 & 5,00 & $\mathrm{CI}$ & 0,0193573 & \\
\hline Talep & 0,33 & 1,00 & 3,00 & RI & 0,58 & \\
\hline $\begin{array}{c}\text { Tedarikçi } \\
\text { Güvenirliği }\end{array}$ & 0,20 & 0,33 & 1,00 & $\mathrm{CR}=\mathrm{CI} / \mathrm{RI}$ & 0,0333747 & \\
\hline TOPLAMLAR & 1,53 & 4,33 & 9,00 & & & \\
\hline 2. Uzman & Fiyat & Talep & $\begin{array}{c}\text { Tedarikçi } \\
\text { Güvenirliği }\end{array}$ & & & \multirow{5}{*}{$\mathrm{n}=3$ için } \\
\hline Fiyat & 1,00 & 1,00 & 5,00 & $\mathrm{CI}$ & 0,0145648 & \\
\hline Talep & 1,00 & 1,00 & 3,00 & RI & 0,58 & \\
\hline $\begin{array}{c}\text { Tedarikçi } \\
\text { Güvenirliği }\end{array}$ & 0,20 & 0,33 & 1,00 & $\mathrm{CR}=\mathrm{CI} / \mathrm{RI}$ & 0,0251118 & \\
\hline TOPLAMLAR & 2,20 & 2,33 & 9,00 & & & \\
\hline 3. Uzman & Fiyat & Talep & $\begin{array}{c}\text { Tedarikçi } \\
\text { Güvenirliği }\end{array}$ & & & \multirow{5}{*}{$n=3$ için } \\
\hline Fiyat & 1,00 & 0,20 & 1,00 & $\mathrm{CI}$ & 0,0145996 & \\
\hline Talep & 5,00 & 1,00 & 3,00 & RI & 0,58 & \\
\hline $\begin{array}{c}\text { Tedarikçi } \\
\text { Güvenirliği }\end{array}$ & 1,00 & 0,33 & 1,00 & $\mathrm{CR}=\mathrm{CI} / \mathrm{RI}$ & 0,0251717 & \\
\hline TOPLAMLAR & 7,00 & 1,53 & 5,00 & & & \\
\hline 4. Uzman & Fiyat & Talep & $\begin{array}{c}\text { Tedarikçi } \\
\text { Güvenirliği }\end{array}$ & & & \multirow{5}{*}{$\mathrm{n}=3$ için } \\
\hline Fiyat & 1,00 & 5,00 & 9,00 & $\mathrm{CI}$ & 0,0146386 & \\
\hline Talep & 0,20 & 1,00 & 3,00 & RI & 0,58 & \\
\hline $\begin{array}{c}\text { Tedarikçi } \\
\text { Güvenirliği }\end{array}$ & 0,11 & 0,33 & 1,00 & $\mathrm{CR}=\mathrm{CI} / \mathrm{RI}$ & 0,0252389 & \\
\hline TOPLAMLAR & 1,31 & 6,33 & 13,00 & & & \\
\hline 5. Uzman & Fiyat & Talep & $\begin{array}{c}\text { Tedarikçi } \\
\text { Güvenirliği }\end{array}$ & & & \multirow{5}{*}{$\mathrm{n}=3$ için } \\
\hline Fiyat & 1,00 & 1,00 & 7,00 & $\mathrm{CI}$ & 0,0063043 & \\
\hline Talep & 1,00 & 1,00 & 5,00 & RI & 0,58 & \\
\hline $\begin{array}{c}\text { Tedarikçi } \\
\text { Güvenirliği }\end{array}$ & 0,14 & 0,20 & 1,00 & $\mathrm{CR}=\mathrm{CI} / \mathrm{RI}$ & 0,0108694 & \\
\hline TOPLAMLAR & 2,14 & 2,20 & 13,00 & & & \\
\hline 6. Uzman & Fiyat & Talep & $\begin{array}{c}\text { Tedarikçi } \\
\text { Güvenirliği }\end{array}$ & & & \multirow{4}{*}{$\mathrm{n}=3$ için } \\
\hline Fiyat & 1,00 & 1,00 & 9,00 & $\mathrm{CI}$ & 0,0035137 & \\
\hline Talep & 1,00 & 1,00 & 7,00 & RI & 0,58 & \\
\hline $\begin{array}{c}\text { Tedarikçi } \\
\text { Güvenirliği } \\
\end{array}$ & 0,11 & 0,14 & 1,00 & $\mathrm{CR}=\mathrm{CI} / \mathrm{RI}$ & 0,0060581 & \\
\hline TOPLAMLAR & 2,11 & 2,14 & 17,00 & & & \\
\hline
\end{tabular}


Yukarıda da görüldüğü üzere İKM’lerin ortalamaları alınmıștır ve geometrik ortalama sonuçlarına istinaden oluşturulan tek bir İKM elde edilmiştir. Bu sonuçlar da Tablo 6’ da detaylı olarak gösterilmektedir.

Tablo 6: Geometrik Ortalama Sonucu Elde Edilen İKM Sonuçları

\begin{tabular}{|c|c|c|c|c|}
\hline ORTALAMA & Fiyat & Talep & Tedarikçi Güvenirliği & \\
\hline Fiyat & 1,00 & 1,20 & 4,92 & \\
\hline Talep & 0,83 & 1,00 & 3,76 & \\
\hline $\begin{array}{c}\text { Tedarikçi } \\
\text { Güvenirliği }\end{array}$ & 0,20 & 0,27 & 1,00 & \\
\hline TOPLAMLAR & 2,04 & 2,47 & 9,68 & \\
\hline & Fiyat & Talep & Tedarikçi Güvenirliği & ORTALAMA \\
\hline Fiyat & 0,49 & 0,49 & 0,51 & 0,4953835 \\
\hline Talep & 0,41 & 0,41 & 0,39 & 0,4009869 \\
\hline $\begin{array}{c}\text { Tedarikçi } \\
\text { Güvenirliği }\end{array}$ & 0,10 & 0,11 & 0,10 & 0,1036296 \\
\hline TOPLAMLAR & 1,00 & 1,00 & 1,00 & 1,0000000 \\
\hline \multirow{2}{*}{\multicolumn{2}{|c|}{ Tüm Öncelikler Matrisi }} & & & $\begin{array}{c}\text { Ortalama/ Tüm Öncelikler } \\
\text { Matrisi }\end{array}$ \\
\hline & & & & 3,00121 \\
\hline Fiyat & 1,486749 & & & 3,00096 \\
\hline Talep & 1,203345 & & & 3,00025 \\
\hline \multirow[t]{4}{*}{$\begin{array}{c}\text { Tedarikçi } \\
\text { Güvenirliliği }\end{array}$} & 0,310915 & & Ortalama & 3,00081 \\
\hline & & $\mathrm{CI}$ & 0,00040 & \\
\hline & & RI & 0,58000 & $\mathrm{n}=3$ için \\
\hline & & $\mathrm{CR}=\mathrm{CI} / \mathrm{RI}$ & 0,00069 & \\
\hline
\end{tabular}

Yukarıdaki anketlerin geometrik ortalamasının tutarlı olup olmadığ hesaplanmıştır. Bu hesaplamalar AHP’nin sıralamasına göre yapılmış ve sonuç 0,00069 olarak bulunmuştur. Yani 0,00069<0,1 olduğu için sonuç tutar sınırları içerisindedir. AHP sonuçlarına göre kriterlerin aldığı ağırlıklara istinaden önemlilik sıralaması aşağıda Tablo 7'de verilmektedir.

Tablo 7: Kriterlerin Önemlilik Sıralaması

\begin{tabular}{|c|c|c|}
\hline Sıra No & Kriterler & Aldığı Ağırlıklar \\
\hline $\mathbf{1 .}$ & Fiyat & 0,4953835 \\
\hline $\mathbf{2}$ & Talep & 0,4009869 \\
\hline $\mathbf{3 .}$ & Tedarikçi Güvenirliği & 0,1036296 \\
\hline
\end{tabular}


Bu sonuçlara göre stok kontrolü açısından en önemli kriter fiyat olarak elde edilmiştir. Tedarikçi güvenirliliği kriteri ise bu sıralamada son sırada yer almaktadır. Bu sonuçlara göre tedarikçi güvenilirliği kriterinin en düşük ağırlığa sahip olduğu gözlenmiştir. Bundan sonraki aşamada ise AHP yöntemi ile belirlenmiş olan kriter ağırlıkları TOPSIS yönteminde kullanılmaktadır.

\subsubsection{TOPSIS Yöntemiyle Sıralama ve Sınıflandırma}

TOPSIS yönteminde, AHP analiz yöntemiyle bulunmuş olan kriter ağırlıkları baz alınmıştır. Ayrıca tedarikçi güvenirliliği ve stok verileriyle ilgili tüm bilgiler yine hastanede çalışan uzmanlar tarafından sağlanarak çalışmaya dahil edilmiştir. Yöntemin uygulanmasındaki amaç; tedarikçi riski, fiyat ve tüketim miktarı kriterlerini baz alarak elde edilen ağırlıklara göre ilaçları önem sırasına göre sıralayabilmesidir. Yani sonuç olarak TOPSIS yöntemi sayesinde önem ve kriterlerin ağırlıklarına göre en sıkı kontrol edilmesi gereken ilaçlar tekrar s1ralanmıştır.

Tedarikçi güvenirliliği uzman görüşleriyle elde edilmiş ve 1-5-9 (En güvenilir tedarikçi-1, orta derece güvenilir tedarikçi-5, en güvenilmez tedarikçi-9) sıralamasıyla yapılmıştır. Veri fazlalığından dolayı 958 çeşit ilacın hepsinin bulunduğu detaylı tablo verilememektedir. Araştırmada kullanılan AHP ve TOPSIS yönteminin işleyişiyle ilgili türetilmiş bir örnek, Tablo 8 ve Tablo 9'da görülmektedir.

Tablo 8'de TOPSIS yöntemiyle ilgili ilk örnek yer almaktadır. Talep, fiyat ve tedarikçi güvenilirliği için AHP yönteminden alınan ağırlıklar ve her stok kaleminin bu kriterlere göre değerleri kullanılarak TOPSIS yöntemi uygulanmıştır. İlk sütün ilacın kodunu göstermektedir. Yıllık talep, birim fiyat ve tedarikçi güvenilirliği sırasıyla ikinci, üçüncü ve dördüncü sütunlarda görülmektedir. İkinci üçüncü ve dördüncü sütunların ilk satırını AHP yöntemiyle elde edilen ağırlıklar oluşturmaktadır. TOPSIS yöntemine göre ideal uzaklık ve negatif ideal uzaklık sırasıyla beşinci ve altıncı sütunlarda görülmektedir. Elde edilen $\mathrm{C}^{\star} i$ değerleri ise yedinci sütundadır. $C^{\star} i$ değerlerine göre oluşturulan sıralama ise son sütunda görülmektedir. Tablo 8'de tedarikçi güvenilirliği her tedarikçi açısından eşit olarak alınmıştır. Eşit alınmasının amacı daha önce kullanılan kriterlere ek olarak kullanılan tedarikçi güvenilirliği kriterinin etkisiz bırakılarak daha sonra (Tablo 9) tedarikçi güvenilirliklerini değiştirip bu kriterin sıralamadaki etkisini gözlemlemektir. Tablo 9'daki ikinci TOPSIS örneğinde tedarikçi güvenilirliği değerleri değiştirilmiştir. Bunun sonucu olarak, tedarikçi güvenilirliği değerleri 5'ten 9'a çıkan yani orta derecede güvenilir tedarikçiden en güvenilmez tedarikçiye geçen 36410, 45106 ve 48627 kodlu ilaçlar sıralamada daha yukarı çıkmışlardır. Dolayısıyla tedarikçi güvenilirliği azaldıkça daha sık kontrol edilmeleri gerektiğinden sıralamada daha yukarıda yer almaları mantıklıdır. Bunun yanında tedarikçi güvenilirliği değerleri 5'ten l'e inen yani orta derecede güvenilir tedarikçiden en güvenilir tedarikçiye geçen 11567, 41645, 30185 
ve 30638 kodlu ilaçlar sıralamada daha aşağ 1 inmiştir. Bu durum tedarikçi güvenilirliği daha yüksek olan stok kaleminin daha gevşek kontrol edilebilmesi düşüncesiyle tutarlıdır.

Sonuç olarak TOPSIS sonucunda daha güvenilir tedarikçilere sahip ilaçlar sıralamada daha altlara inerken daha güvenilmez tedarikçilere sahip olan ilaçlar daha üstlere çıkmaktadır. Sıralamada daha üste çıkma daha sıkı kontrol edilme anlamına gelmektedir. Dolayısıyla daha güvenilmez tedarikçilere sahip ilaçların daha sıkı kontrol gerektirmesi beklenen bir durumdur. TOPSIS modelinin ağırlıklar ölçüsünde beklenen şekilde daha güvenilmez tedarikçilere sahip ilaçlarının sıralamada daha üste çıkardığı görülmektedir.

Tablo 8: İlk TOPSIS Örneği

\begin{tabular}{|c|c|c|c|c|c|c|c|}
\hline & 0,401 & 0,495 & 0,104 & & & & \\
\hline $\begin{array}{l}\text { İlaç } \\
\text { kod }\end{array}$ & Talep & Fiyat & $\operatorname{tg} 1$ & $S^{*_{i}}$ & S-i & $C^{\star_{i}}$ & Sira \\
\hline 18746 & 19008 & 1,47 & 5 & 0,31 & 0,31 & 0,502 & 1 \\
\hline 46070 & 100 & 271,5 & 5 & 0,31 & 0,31 & 0,498 & 2 \\
\hline 48968 & 115 & 234,7 & 5 & 0,31 & 0,27 & 0,460 & 3 \\
\hline 73837 & 448 & 188,6 & 5 & 0,32 & 0,21 & 0,401 & 4 \\
\hline 44614 & 10432 & 2,59 & 5 & 0,34 & 0,17 & 0,334 & 5 \\
\hline 37345 & 7897 & 3,85 & 5 & 0,36 & 0,13 & 0,265 & 6 \\
\hline 67034 & 332 & 86,72 & 5 & 0,37 & 0,10 & 0,208 & 7 \\
\hline 11567 & 384 & 74,94 & 5 & 0,38 & 0,08 & 0,181 & 8 \\
\hline 36410 & 489 & 73,12 & 5 & 0,38 & 0,08 & 0,178 & 9 \\
\hline 41645 & 4477 & 5,89 & 5 & 0,39 & 0,07 & 0,157 & 10 \\
\hline 45106 & 306 & 59,27 & 5 & 0,39 & 0,07 & 0,145 & 11 \\
\hline 76435 & 3757 & 3,8 & 5 & 0,40 & 0,06 & 0,132 & 12 \\
\hline 41219 & 2693 & 21,15 & 5 & 0,39 & 0,05 & 0,109 & 13 \\
\hline 52785 & 2481 & 5,81 & 5 & 0,41 & 0,04 & 0,088 & 14 \\
\hline 30185 & 2409 & 8,06 & 5 & 0,41 & 0,04 & 0,087 & 15 \\
\hline 30638 & 1557 & 16,14 & 5 & 0,41 & 0,03 & 0,067 & 16 \\
\hline 51380 & 1386 & 16,71 & 5 & 0,41 & 0,03 & 0,063 & 17 \\
\hline 75937 & 1522 & 12,34 & 5 & 0,41 & 0,03 & 0,060 & 18 \\
\hline 48627 & 1165 & 16,6 & 5 & 0,41 & 0,02 & 0,056 & 19 \\
\hline 73215 & 1392 & 12,41 & 5 & 0,41 & 0,02 & 0,056 & 20 \\
\hline
\end{tabular}

Tablo 9: İkinci TOPSIS Örneği

\begin{tabular}{|c|c|c|c|c|c|c|c|}
\hline & 0,401 & 0,495 & 0,104 & & & & \\
\hline $\begin{array}{l}\text { İlaç } \\
\text { kod }\end{array}$ & Talep & Fiyat & $\operatorname{tg} 2$ & $S^{*} \mathbf{i}$ & S-i & $C^{*} \mathbf{i}$ & Sira \\
\hline 18746 & 19008 & 1,47 & 5 & 0,31 & 0,31 & 0,502 & 1 \\
\hline 46070 & 100 & 271 & 5 & 0,31 & 0,31 & \begin{tabular}{|l|}
0,498 \\
\end{tabular} & 2 \\
\hline 48968 & 115 & 235 & 5 & 0,31 & 0,27 & 0,460 & 3 \\
\hline 73837 & 448 & 189 & 5 & 0,32 & 0,21 & \begin{tabular}{|l|}
0,402 \\
\end{tabular} & 4 \\
\hline 44614 & 10432 & 2,59 & 5 & 0,34 & 0,17 & \begin{tabular}{|l|}
0,335 \\
\end{tabular} & 5 \\
\hline 37345 & 7897 & 3,85 & 5 & 0,36 & 0,13 & 0,266 & 6 \\
\hline 67034 & 332 & 86,7 & 5 & 0,37 & 0,10 & 0,210 & 7 \\
\hline 36410 & 489 & 73,1 & 9 & 0,38 & 0,09 & \begin{tabular}{|l|}
0,189 \\
\end{tabular} & 8 \\
\hline 11567 & 384 & 74,9 & 1 & 0,38 & 0,08 & \begin{tabular}{|l|}
0,181 \\
\end{tabular} & 9 \\
\hline 45106 & 306 & 59,3 & 9 & 0,39 & 0,07 & \begin{tabular}{|l|}
0,158 \\
\end{tabular} & 10 \\
\hline 41645 & 4477 & 5,89 & 1 & 0,39 & 0,07 & 0,157 & 11 \\
\hline 76435 & 3757 & 3,8 & 5 & 0,40 & 0,06 & 0,136 & 12 \\
\hline 41219 & 2693 & 21,2 & 5 & 0,39 & 0,05 & \begin{tabular}{|l|}
0,115 \\
\end{tabular} & 13 \\
\hline 52785 & 2481 & 5,81 & 5 & 0,41 & 0,04 & 0,095 & 14 \\
\hline 48627 & 1165 & 16,6 & 9 & 0,41 & 0,04 & \begin{tabular}{|l|}
0,090 \\
\end{tabular} & 15 \\
\hline 30185 & 2409 & 8,06 & 1 & 0,41 & \begin{tabular}{|l|}
0,04 \\
\end{tabular} & 0,087 & 16 \\
\hline 51380 & 1386 & 16,7 & 5 & 0,41 & 0,03 & 0,072 & 17 \\
\hline 75937 & 1522 & 12,3 & 5 & 0,41 & 0,03 & \begin{tabular}{|l|}
0,070 \\
\end{tabular} & 18 \\
\hline 73215 & 1392 & 12,4 & 5 & 0,41 & 0,03 & 0,066 & 19 \\
\hline 30638 & 1557 & 16,1 & 1 & 0,41 & 0,03 & 0,066 & 20 \\
\hline
\end{tabular}

Elde edilen tüm verilerle ve aynı prosedürle AHP ve TOPSIS yöntemi kullanılarak sıralama sonuçları elde edilmiştir. TOPSIS sonucu elde edilen $C^{\star} i$ değerlerine göre ilaçlar büyükten küçüğe sıralanmıştır. Bu yeni sıralamada ilaçların kümülatif tüketim değerine bakılarak, kümülatif tüketim değeri \%80’e kadar olanlar A grubunda, \%81-\%95 arası B grubunda, kalanı da C grubunda yer alacak şekilde yeni A, B, C sınıfları elde edilmiştir. Bu sonuçlara istinaden, ilk yapılan $\mathrm{ABC}$ yöntemindeki ilaçlarla karşılaştırma yapıldığında değişim Tablo 10'da, ilk ABC analizinde ve TOPSIS sonrası gerçekleştirilen yeni ABC analizinde her gruptaki ilaç miktarı ve değerleri Tablo 11'de görülmektedir. İlaç gruplarının değişmesinin üç temel sebebi bulunmaktadır. Birincisi, ABC analizi ile TOPSIS analizinin matematiksel 
yapısından kaynaklanmaktadır. İkincisi, ABC analizinde fiyat ve tüketim miktarı kriterleri sadece çarpılıp ağırlık kullanılmazken, TOPSIS yönteminde her kriterin bir ağırlığının olmasıdır. Üçüncüsü de $\mathrm{ABC}$ analizinde sadece fiyat ve tüketim miktarı kriterleri kullanılırken, TOPSIS yönteminde bunlara ek olarak tedarikçi güvenilirliği kriterinin kullanılmış olmasidir.

Tablo 10: TOPSIS Yöntemiyle Değişim Yaşayan Grup Tablosu

\begin{tabular}{|c|c|}
\hline Çeşit & İlaç Grupları \\
\hline 17 & ABC'de A Grubu iken TOPSIS'le B Grubu Olanlar \\
\hline 37 & ABC'de B Grubu iken TOPSIS'le A Grubu Olanlar \\
\hline 22 & ABC'de B Grubu iken TOPSIS'le C Grubu Olanlar \\
\hline 47 & ABC'de C Grubu iken TOPSIS'le A Grubu Olanlar \\
\hline 73 & ABC'de C Grubu iken TOPSIS'le B Grubu Olanlar \\
\hline 74 & Yine A Grubu Kalanlar \\
\hline 69 & Yine B Grubu Kalanlar \\
\hline 619 & Yine C Grubu Kalanlar \\
\hline $\mathbf{9 5 8}$ & TOPLAM \\
\hline
\end{tabular}

\section{TARTIŞMA}

AHP ve TOPSIS yöntemleriyle elde edilen sonuçlar baz alınarak tekrardan ABC ve VED analizleri yapılmış ve yeni bir ABC-VED matrisi oluşturulmuştur (Tablo 11). Yapılan bu analizler sonucunda iki tane ABC-VED matrisi elde edilmiştir. Aşağıdaki tablolarda tek tek k1yaslama yapılmaktadır. Sonuçlar ilk yapılan ABC-VED yöntemine kıyasla yorumlanmaktadir.

Tablo 11: ABC Yöntemi Sonucunda Elde Edilen Tabloların Kıyaslanması

\begin{tabular}{|c|c|c|c|c|}
\hline \multicolumn{5}{|c|}{ ABC Analizi Sonuçları } \\
\hline Gruplar & İlaç Miktarı (\%) & İlaç Miktarı & İlaç Maliyeti (\%) & İlaç Maliyeti \\
\hline A & 10 & 91 & 80 & 1008793,44 \\
\hline B & 13 & 128 & 15 & 190245,46 \\
\hline C & 77 & 739 & 5 & 63559,57 \\
\hline TOPLAM & $\mathbf{1 0 0}$ & $\mathbf{9 5 8}$ & $\mathbf{1 0 0}$ & $\mathbf{1 2 6 2 5 9 8 , 4 7}$ \\
\hline \multicolumn{5}{|c|}{ TOPSIS Sonrası Yeni ABC Analizi Sonuçları } \\
\hline Gruplar & İlaç Miktarı (\%) & İlaç Miktarı & İlaç Maliyeti (\%) & İlaç Maliyeti \\
\hline Yeni A & 16 & 158 & 80 & 1009097,35 \\
\hline Yeni B & 17 & 159 & 15 & 189773,72 \\
\hline Yeni C & 67 & 641 & 5 & 63727,40 \\
\hline TOPLAM & $\mathbf{1 0 0}$ & $\mathbf{9 5 8}$ & $\mathbf{1 0 0}$ & $\mathbf{1 2 6 2 5 9 8 , 4 7}$ \\
\hline
\end{tabular}


Yeni A sınıfı toplam ilaç miktarının \%16'sını toplam tüketim değerinin ise \%80'ini oluşturmaktadır (toplam tüketim değerinde sınıfların oranı, karşılaştırma yapabilmek amacıyla ilk ABC analizinde olduğu gibi A \%80, B \%15, C \%5 olarak alınmıştır). İlk ABC analizinde bu oran \%10 - \%80 şeklindeydi. B grubu ilaçlar için TOPSIS sonucu elde edilen oran \%17 \%15 şeklinde olurken, ilk ABC analizinde bu oran \%13 - \%15 şeklindeydi. C grubu ilaçlar için TOPSIS sonucu elde edilen oran \%67-\%5 şeklinde olurken, ilk ABC analizinde bu oran \%77-\%5 şeklindeydi. Dolayısıyla TOPSIS ile gerçekleştirilen ABC analizinde A ve B grubundaki ilaçların miktarları artmıştır. TOPSIS ile gerçekleştirilen analize göre, klasik ABC analizinden daha fazla ilacın sıkı kontrol edilmesi gerektiği görülmektedir.

VED yöntemiyle elde edilen analiz sonuçları kritiklik kriterinin AHP ve TOPSIS analizine dahil edilmemesinden dolayı VED analiz sonuçları aynıdır. Bununla birlikte TOPSIS sonrası elde edilen yeni ABC analiziyle VED analizinin birleşmesi sonucunda elde edilen yeni ABC-VED matrisi, ilk ABC-VED matrisinden farklı sonuçlar vermektedir çünkü her iki ABC analizi sonuçları farklıdır. İlk ABC-VED matris analizi sonuçları ile yeni ABC-VED matris analizi sonuçları karşılaştırmalı olarak Tablo 12'de gösterilmiştir.

Tablo 12: ABC-VED ve Yeni ABC-VED Matrislerinin Sonuçları

\begin{tabular}{|c|c|c|c|c|c|}
\hline Gruplar & İlaç Miktarı (\%) & İlaç Miktarı & İlaç Maliyeti (\%) & İlaç Maliyeti & \\
\hline $\mathrm{A}+\mathrm{V}$ & 4,28 & 41 & 34,68 & 437896,09 & \\
\hline $\mathrm{A}+\mathrm{E}$ & 3,34 & 32 & 24,68 & 311667,32 & \\
\hline$A+D$ & 1,88 & 18 & 20,53 & 259230,03 & \\
\hline $\mathrm{B}+\mathrm{V}$ & 5,95 & 57 & 7,68 & 96974,14 & \\
\hline $\mathrm{C}+\mathrm{V}$ & 19,31 & 185 & 1,66 & 20939,63 & \\
\hline $\mathrm{B}+\mathrm{E}$ & 4,70 & 45 & 5,12 & 64612,36 & \\
\hline$B+D$ & 2,71 & 26 & 2,27 & 28658,96 & \\
\hline $\mathrm{C}+\mathrm{E}$ & 23,70 & 227 & 1,70 & 21420,26 & \\
\hline $\mathrm{C}+\mathrm{D}$ & 34,13 & 327 & 1,68 & 21199,68 & \\
\hline TOPLAM & 100 & 958 & 100 & 1262598,47 & \\
\hline Kategori & $\begin{array}{c}\text { Çaprazlanan } \\
\text { Gruplar }\end{array}$ & $\begin{array}{c}\text { İlaç Miktarı } \\
(\%)\end{array}$ & İlaç Miktarı & İlaç Maliyeti (\%) & İlaç Maliyeti \\
\hline I & $\begin{array}{c}\mathrm{AV}+\mathrm{AE}+\mathrm{AD}+ \\
\mathrm{BV}+\mathrm{CV}\end{array}$ & 34,76 & 333 & 89,23 & 1126707,21 \\
\hline II & $\mathrm{BE}+\mathrm{BD}+\mathrm{CE}$ & 31,11 & 298 & 9,09 & 114691,58 \\
\hline III & $\mathrm{CD}$ & 34,13 & 327 & 1,68 & 21199,68 \\
\hline TOPLAM & & 100 & 958 & 100 & 1262598,47 \\
\hline \multicolumn{5}{|c|}{ TOPSIS Sonrası Yeni ABC-VED Matris Sonuçları } & \\
\hline Gruplar & İlaç Miktarı (\%) & İlaç Miktarı & İlaç Maliyeti (\%) & İlaç Maliyeti & \\
\hline
\end{tabular}




\begin{tabular}{|c|c|c|c|c|c|}
\hline A+V & 5,22 & 50 & 34,50 & 435571,80 & \\
\hline A+E & 5,74 & 55 & 24,67 & 311426,74 & \\
\hline A+D & 5,53 & 53 & 20,76 & 262098,81 & \\
\hline B+V & 6,89 & 66 & 7,88 & 99537,46 & \\
\hline C+V & 17,43 & 167 & 1,64 & 20700,61 & \\
\hline B+E & 4,91 & 47 & 4,91 & 62044,77 & \\
\hline B+D & 4,80 & 46 & 2,23 & 28191,48 & \\
\hline C+E & 21,09 & 202 & 1,92 & 24228,42 & \\
\hline C+D & 28,39 & 272 & 1,49 & 18798,38 & \\
\hline TOPLAM & $\mathbf{1 0 0}$ & $\mathbf{9 5 8}$ & $\mathbf{1 0 0}$ & $\mathbf{1 2 6 2 5 9 8 , 4 7}$ & \\
\hline & & & & & \\
\hline Kategori & $\begin{array}{c}\text { Caprazlanan } \\
\text { Gruplar }\end{array}$ & $\begin{array}{c}\text { İlaç Miktarı } \\
(\%)\end{array}$ & İlaç Miktarı & İlaç Maliyeti (\%) & İlaç Maliyeti \\
\hline I & $\begin{array}{c}\text { AV+AE+AD+ } \\
\text { BV+CV }\end{array}$ & 40,81 & 391 & 89,45 & \multirow{2}{*}{1129335,41} \\
\hline II & BE+BD+CE & 30,80 & 295 & 9,06 & 114464,68 \\
\hline III & CD & 28,39 & 272 & 1,49 & 18798,38 \\
\hline TOPLAM & & $\mathbf{1 0 0}$ & $\mathbf{9 5 8}$ & $\mathbf{1 0 0}$ & $\mathbf{1 2 6 2 5 9 8 , 4 7}$ \\
\hline
\end{tabular}

Tablo 12'de görülen sonuçlara göre ilk ABC-VED matrisinde birinci kategoride yer alan 333 çeşit ilaç yıllık tüketim değerinin \%89,23’ünü oluşturmaktadır. Bu durum yeni ABCVED matrisinde biraz değişiklik göstermiştir. İlaç çeşidi artıp 391'e yükselirken, yıllık tüketim değeri oranı hemen hemen aynı kalarak \%89,45 olmuştur. Burada dikkate edilmesi gereken konu tedarikçi güvenilirliği kriteri dahil olduğunda $\mathrm{A}+\mathrm{V}$ gruplarından oluşan en kritik kategorinin toplam tüketim değeri içindeki payı aynı kalırken, bu kategorideki ilaç sayısı artmamasıdır. VED sonuçları her iki analiz için de aynı olduğuna göre, yeni ABC analizi sonucunda A, B ve C sınıflarının değişmesi, yeni ABC-VED analizinde de kategoriler altındaki ilaçların değişimine sebep olmuştur.

ABC-VED matris analizine göre ikinci kategoride yer alan 298 çeşit ilaç, toplam tüketim değerinin \% 9,09'unu oluşturmaktadır. Yeni ABC-VED matris analiziyle neredeyse aynı orandadır. Yeni ABC-VED analizinde II. kategori 295 ilaç çeşidini içerirken toplam tüketim değerinin de \%9,06’unu kapsamaktadır. Üçüncü kategoriye bakıldığında ABC-VED matrisindeki 327 çeşit ilaç maliyetin \%1,68'ini oluşturmaktadır. Yeni ABC-VED matrisinde ise 272 çeşit ilaç maliyetin \%1,49’unu oluşturmaktadır.

Ayrıca daha önceden sağlık sektöründe yapılmış olan ABC-VED matrisi sonuçları ile bu çalışmada bulunan matrislerin sonuçlarının karşılaştırıldığı tablo aşağıda gösterilmektedir (Tablo 13). Tablo oluşturulurken Savaş (2018), Yeşilyurt (2014), Yiğit, Dikmetaş, Ağırbaş \& Tengilimoğlu (2010), Wandalkar vd. (2013), Uygun (2016), Uygun \& Yiğit (2016), Yiğit (2014), Karagöz \& Yıldız (2015), Vaz vd. (2008a), Khurana, Chhillar \& Gautam (2013), Nigah vd. (2010), Roy, Manna \& Sarker (2010), Mani, Annadurai, Danasekaran, District \& 
Nadu (2014), Vaz vd. (2008b), Pund, Kuril, Hashmi, Doibale \& Doifode (2017), Singh vd. (2015), Pirankar vd. (2014) ve Uygun \& Yiğit (2017) kaynaklarından yararlanılmıştır.

Tablo 13: ABC-VED Matrislerinin Diğer Matrislerle Karşılaştırması

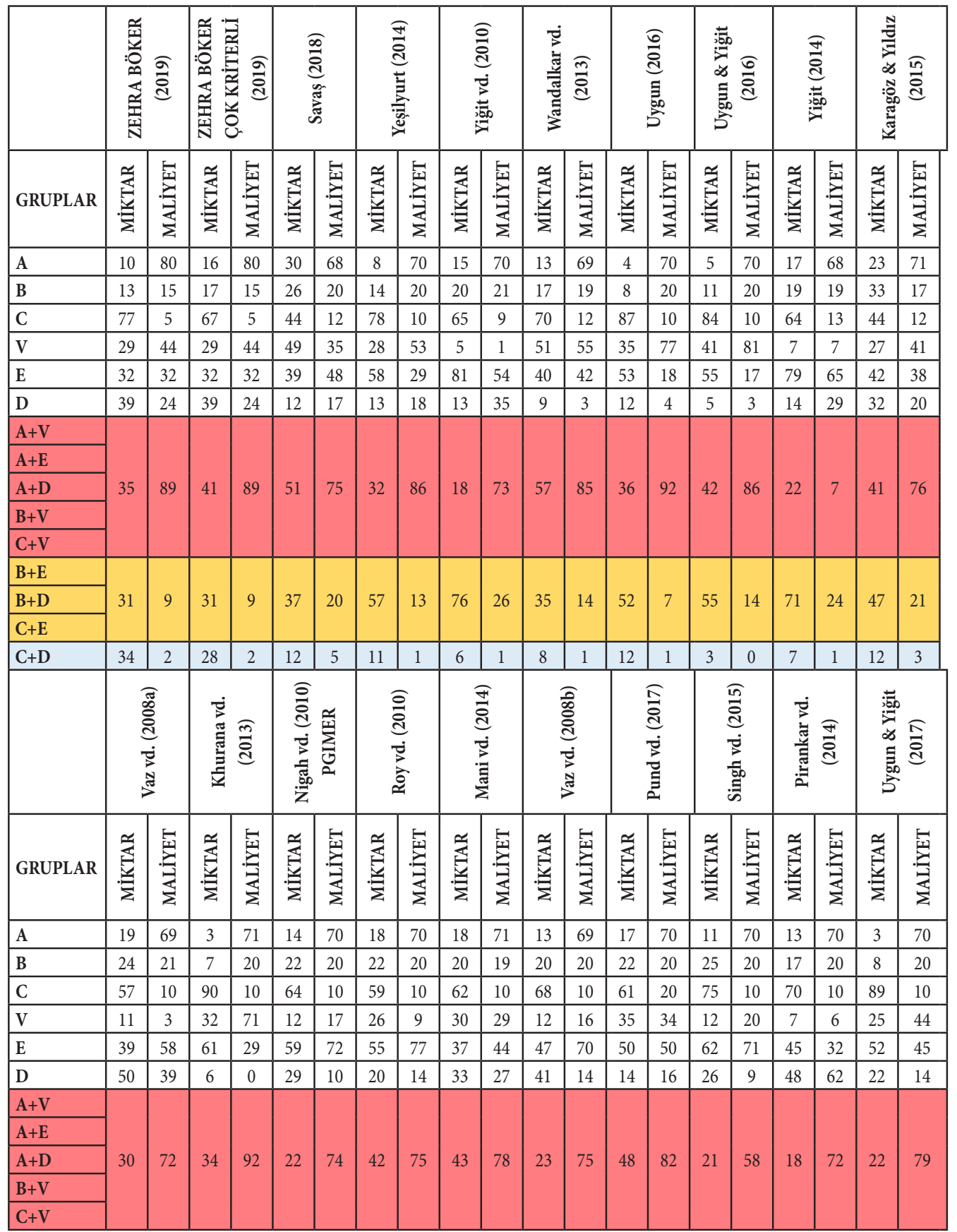




\begin{tabular}{|c|c|c|c|c|c|c|c|c|c|c|c|c|c|c|c|c|c|c|c|c|}
\hline $\mathrm{B}+\mathrm{E}$ & \multirow{3}{*}{42} & \multirow{3}{*}{23} & \multirow{3}{*}{60} & \multirow{3}{*}{7} & \multirow{3}{*}{55} & \multirow{3}{*}{22} & \multirow{3}{*}{44} & \multirow{3}{*}{22} & \multirow{3}{*}{37} & \multirow{3}{*}{17} & \multirow{3}{*}{42} & \multirow{3}{*}{22} & \multirow{3}{*}{44} & \multirow{3}{*}{17} & \multirow{3}{*}{58} & \multirow{3}{*}{21} & \multirow{3}{*}{49} & \multirow{3}{*}{24} & \multirow{3}{*}{71} & \multirow{3}{*}{18} \\
\hline$B+D$ & & & & & & & & & & & & & & & & & & & & \\
\hline $\mathrm{C}+\mathrm{E}$ & & & & & & & & & & & & & & & & & & & & \\
\hline$C+D$ & 27 & 5 & 6 & 0 & 23 & 4 & 14 & 3 & 20 & 5 & 35 & 4 & 8 & 1 & 20 & 3 & 33 & 4 & 7 & 3 \\
\hline
\end{tabular}

Literatüre göre oluşturulan Tablo 13’te görüldüğü üzere sağllk sektöründe gerçekleştirilen $\mathrm{ABC}$ analizleri olarak A grubundaki stoklar için \%80-\%20 kuralına (yıllık tüketim değerinin $\% 80$ 'i, stok çeşidinin \%20'sinden oluşur kuralı) yakın değerler vermemektedir. Hatta \%70-\%4 veya \%68-\%30 gibi oldukça farklı değerler de bulunmaktadır. Bunun nedeni sağlık sektörlerinin farklı yapılarından ve çalışmaların farklı hastanelerde yapılmış olmasından kaynaklanmasıdır. Çalışmada bu oran \%80 - \%10 şeklindedir. Her ABC analizindeki A grubu ile ABC-VED matris analizindeki I. kategori karşılaştırılmış olup toplam tüketim değeri açısından I. kategorinin ve A grubunun hemen hemen eşit (1,12 katı) olduğu gözlemlenmiştir. İçerdiği ilaç çeşidi oranı açısından I. kategorideki ilaç oranının, A grubundaki ilaç oranının yaklaşık üç katı (3,39 katı) olduğu gözlemlenmiştir. Başka bir ifadeyle literatürdeki çalışmalara göre ortalama olarak VED analizi ile A grubuna eklenen V grubu stokların parasal değer açısından yüksek olmamakla birlikte çeşit olarak fazla olduğu görülmektedir. $\mathrm{Bu}$ çalışmada elde edilen bulgular literatürdekilerin ortalamasına benzerdir. Bu çalışmaya özgü olarak eklenen tedarikçi güvenilirliği kriteri ise klasik ABC-VED analizine göre \%35 olan I. kategorideki ilaç çeşidi oranını \%4l'e çıkarmaktadır.

\section{SONUÇ ve ÖNERILER}

ABC-VED matris yöntemini kullanarak stok sınıflandırması yapan birçok yerli ve yabancı çalışmalar bulunmaktadır. Literatürdeki çalışmalar incelendiğinde öncelikle sağlık sektörü açısından genel bir \%80-\%20 kuralına uygunluğun olmadığı söylenebilir. Bunun yanında literatürdeki çalışmalara göre ortalama olarak VED analizi ile A grubuna eklenen V grubu stokların parasal değer açısından yüksek olmamakla birlikte çeşit olarak fazla olduğu dikkat çekicidir. Sağlık işletmelerinin sadece fiyat, tüketim miktarı kriterlerine odaklanması sıkı kontrol edilmesi gereken $\mathrm{V}$ grubunu ihmal etmesi anlamına gelmektedir ki, $\mathrm{V}$ grubunda azımsanmayacak derecede fazla stok bulunmaktadır.

Yapılan bu çalışmada sadece ABC-VED analizi gerçekleştirilmemiştir. Fiyat talep ve kritiklik kriterlerinin yanına tedarikçi güvenilirliği kriterinin de eklendiği ve AHP ve TOPSIS yöntemlerinin kullanıldığı yeni bir sınıflandırma yöntemi olarak çok kriterli ABC-VED matris yöntemiyle yeniden stok sınıflandırılması yapılmıştır. Böylelikle elde edilen iki matris sonuçları karşılaştırılmış ve çok kriterli ABC-VED matris çalışmasının, sağlı sektöründe yapılmış stok sınıflandırmalarından daha farklı sonuçlar ortaya koyduğu görülmüştür. TOPSIS ile gerçekleştirilen $\mathrm{ABC}$ analizinde $\mathrm{A}$ ve $\mathrm{B}$ grubundaki ilaçların miktarları artmıştır. TOPSIS ile gerçekleştirilen ABC-VED analize göre, klasik ABC-VED analizinden daha fazla ilacın sıkı kontrol edilmesi gerektiği görülmektedir. Aradaki farkın sebeplerinden birisi tedarikçi 
güvenilirliği kriterinin eklenmiş olmasıdır. Dolayısıyla sağlık kuruluşları tedarikçi güvenilirliği kriterini de dikkate alarak özellikle $\mathrm{V}$ grubu ilaçlar açısından bu riskten kendilerini bertaraf etmeye çalışmalıdırlar.

Stok yönetimi her sektörde önemli olduğu gibi sağlık sektöründe büyük önem arz etmektedir. Hastaneler, ilaç tedarikçilerinden kaynaklanabilecek temin riskine karşı önlem alabilmek için stok kontrolünü ve stok sınıflandırmasına dikkat etmelidir. Aksi durumda stok sınıflandırmasını iyi yapmayan hastaneler hem hayati ve gerekli ilaç ve tıbbi malzemelerin temini konusunda sıkıntı yaşayabileceklerdir hem de maliyet açısından zarara uğrayacaklardir.

Çalışmada sonuç olarak, yapılan iki farklı sınıflandırmada toplam tüketim değeri açısından çok büyük bir fark görülmediği fakat ilaç çeşitlerinde değişimlerin meydana geldiği görülmüştür. Tedarikçi güvenilirliği işin içine girdiğine $\mathrm{A}+\mathrm{V}$ grubu ve en kritik I. kategoride daha fazla ilacın yer aldığı görülmektedir. Aslında hastaneler tedarikçi güvenilirliği kriterini dikkate alarak bu kategoride yer alan ilaçları doğru belirlemeliler ki hayati açıdan önemli olan bu ilaçlarla ilgili temin sıkıntısı yaşamasınlar.

Literatür açısından bakıldığında tedarikçi güvenilirliğini sağlık sektöründe ek bir kriter olarak alıp ABC-VED matrisinin oluşturulmasında kullanan çalışma sayısı bilgimizce sınırlıdır. Dolayısıyla çalışmanın bu açıdan literatüre katkı sağlayacağı düşünülmektedir. İleriki çalışmalarda tedarikçi güvenilirliği faktörünü içine alan ABC-VED analizi çalışmaları farklı ÇKKV yöntemleriyle denenebilir.

$\mathrm{Bu}$ çalışmada hastanenin sadece ilaç verileri kullanılmıştır. Fakat ileride bütün stok kalemleri de dâhil edilerek veya daha farklı kriterler de eklenerek çok kriterli stok sınıflandırması yapılabilir. Hastanenin kaynaklarının optimal kullanımı, stoksuz kalmanın ortaya çıkaracağı riskin ortadan kaldırılması ve daha iyi bir stok yönetimi sağlanması için sağlık sektörüne özgü stok kontrol ve stok yönetimi çalı̧smalarına gerek akademik gerek pratik alanda ihtiyaç duyulduğu söylenebilir. Bu çalışma, sağlık sektöründe stok sınıflandırması adı altında ABC, VED ve AHP, TOPSIS yöntemlerinin bir arada kullanıldığı sınırlı sayıdaki çalışma arasında olduğundan, bundan sonraki çalışmalar için de örnek olabileceği düşünülmektedir.

\section{KAYNAKÇA}

Ağırbaş, İ. (2013). Sağllk Kurumlarında Finansal Yönetim. Eskişehir: Anadolu Üniveristesi Yayınlar1.

Akman, M. (2003). Hastanelerde Lojistik Yönetim. İstanbul: Nobel Tip Kitabevleri.

Altuğ, O. \& Özhan, Ş. (2017). Sağhlk Hizmetleri Pazarlaması. Çanakkale: Paradigma Akademi BasınYayın Dağıtım. 
Başyazıcı, B. B. (2010). Stok Yönetimi ve Stratejik Satın Alma. (Yayınlanmamış yüksek lisans tezi). Niğde Üniversitesi, Niğde

Behzadian, M., Otaghsara, S.K., Yazdani, M. \& Ignatius, J. (2012). A State-Of The-Art Survey Of TOPSIS Applications. Expert Systems with Applications, 39, 13051-13069.

Bhattacharya, A., Sarkar, B. \& Mukherjee, S. K. (2007). Distance-based consensus method for ABC analysis. International Journal of Production Research, 45(15), 3405-3420.

Chen, C. T. (2000). Extensions of the TOPSIS for group decision-making under fuzzy environment. Fuzzy sets and systems, 114(1), 1-9.

Chen, Y., Li, K. W., Kilgour, D. M. \& Hipel, K. W. (2008). A case-based distance model for multiple criteria ABC analysis. Computers \& Operations Research, 35(3), 776-796.

Chu, C. W., Liang, G. S. \& Liao, C. T. (2008). Controlling inventory by combining ABC analysis and fuzzy classification. Computers \& Industrial Engineering, 55(4), 841-851.

Çakır, O. \& Canbolat, M. S. (2008). A web-based decision support system for multicriteria inventory classification using fuzzy ahp methodology. Expert Systems With Applications, 35(3), 1367-1378.

Demir, H. \& Gümüşoğlu, Ş. (2009). Üretim Yönetimi / İşlemler Yönetimi. İstanbul: Beta Basım Yayım, (7.Baskı).

Demireli, E. (2010). TOPSIS çok kriterli karar verme sistemi: Türkiye’deki kamu bankaları üzerine bir uygulama. Girişimcilik ve Kalkınma Dergisi, 5(1), 101-112.

Doğanay, P. (2008). Kaizen-Sürekli İyileştirme ile Hastalerde İnsan Kaynaklarının Geliştirilmesi. (Yayınlanmamış yüksek lisans tezi). Gazi Üniversitesi, Ankara.

Ernst, R. \& Cohen, M. A. (1990). Operations related groups (Orgs): A clustering procedure for production/ inventory systems. Journal of Operations Management, 9(4), 574-598.

Filiz, A. (2008). Üretim Yönetiminde Verimlilik Sirları. İstanbul: Sistem Yayıncılık.

Fitriana, I., Satria, R. G. D., \& Setiawan, D. C. B. (2018). Medicine inventory management by ABC-VED analysis in the pharmacy store of veterinary hospital, Yogyakarta, Indonesia. Asian Journal of Animal and Veterinary Advances, 13(1), 85-90.

Flores, B. E., \& Whybark, D. C. (1987). Implementing multiple criteria ABC analysis. Journal of Operations Management, 7(1-2), 79-85.

Flores, B. E., Olson, D. L., \& Dorai, V. K. (1992). Management of multicriteria inventory classification. Mathematical and Computer Modelling, 16(12), 71-82.

Ghosh, D. N. (2011). Analytic hierarchy process \& TOPSIS method to evaluate faculty performance in engineering education. Dipendra Nath Ghosh et al UNIASCIT, 1(2), 63-70.

Güvenir, H. A. \& Erel, E. (1998). Multicriteria inventory classification using a genetic algorithm. European Journal of Operational Research, 105(1), 29-37. 
Holmgren, J. H., \& Wentz, W. J. (1982). Material Management and Purchasing for The Health Care Facility. Washington, DC: Aupha Press.

Houska, M. (2012). Reply to the paper "Multi-criteria analysis of economic activity for European Union member states and candidate countries: TOPSIS and WSA applications" by S. E. Dincer. European Journal of Social Sciences, 30(2), 290-295.

Huang, J. Y. (2016). Patent portfolio analysis of the cloud computing industry. Journal of Engineering and Technology Management, 39, 45-64.

Huarng, F. (1998). Hospital material management in Taiwan: a survey. Hospital materiel management quarterly, 19(4), 71-81.

Hussain, M., Siddharth, V. \& Arya, S. (2019). ABC, VED and lead time analysis in the surgical store of a public sector tertiary care hospital in Delhi. Indian journal of public health, 63(3), 194-198.

Hwang, C.L \& Yoon K. (1981). Multiple Attribute Decision Making: Methods and Applications. Springer-Verlag, New York.

Jadidi, O., Firouzi, F. \& Bagliery, E. (2010). TOPSIS method for supplier selection problem. World Academy of Science, Engineering and Technology, 47, 956-958.

Karagöz, F. \& Yıldız, M. S. (2015). Hastane işletmelerinde stok yönetimi için ABC ve VED analizlerinin uygulanması, Yönetim ve Ekonomi Araştırmaları Dergisi, 13(2), 375-396.

Kavuncubaşı, Ş. (2010). Sağlık Kurumları Yönetimi. Eskişehir: Anadolu Üniversitesi Yayınları, (4.Bask1).

Khurana, S., Chhillar, N. \& Gautam, V. K. S. (2013). Inventory control techniques in medical stores of a tertiary care neuropsychiatry hospital in Delhi. Health, 5(1), 8-13.

Kobu, B. (2010). Üretim Yönetimi. İstanbul: Beta Basım, (15.Baskı).

Krajewski, L. J., Ritzman, L. P., \& Malhotra, M. K. (2013). Operations Management: Processes and Supply Chains (10 uppl.). Harlow: Pearson Education Limited. ABD, Pearson.

Kumar Sahu, A. K., Datta, S. \& Mahapatra, S. S. (2016). Evaluation and selection of resilient suppliers in fuzzy environment: exploration of fuzzy-VIKOR. Benchmarking: An International Journal, 23(3), 651-673.

Kuruüzüm, A. \& Atsan, N. (2001). Analitik hiyerarşi yöntemi ve işletmecilik alanındaki uygulamaları. Akdeniz İ.̇..B.F. Dergisi, (1), 83-105.

Küçük, O. (2017). Stok Yönetimi. Ankara: Seçkin Yayıncılık, (4.Baskı).

Lau, H., Nakandla, D., Samaranayake, P. \& Shum, P.K. (2016). BPM for supporting customer relationship and profit decision. Business Process Management Journal, 22(1), 231-255.

Liu, J. \& Li, S. (2015). Research on the ranking of university education based on grey TOPSISDEA method. iJET, 8(10), 51-54. 
Mani, G., Annadurai, K., Danasekaran, R., District, K. \& Nadu, T., (2014), Drug inventory control analysis in a primary level health care facility in rural tamil nadu , India. Healthline, 5(2), 2-6.

Mehralian, G., Nazari, J.A., Rasekh, H.R. \& Hosseini, S. (2016). TOPSIS approach to prioritize critical success factors of TQM. The TQM Journal, 28(2), 235-249.

Monavvarian, A., Fathi, M. R., Zarchi, M. K. \& Faghih, A. (2011). Combining ANP with TOPSIS in selecting knowledge management strategies (case study: pars tire company). European Journal of Scientific Research, 54(4), 538-546.

Mutlu, M. \& Sarı, M. (2017). Çok kriterli karar verme yöntemleri ve madencilik sektöründe kullanımı. Aksaray: Bilimsel Madencilik Dergisi, 56(4),181-196.

Nigah, R., Devnani, M. \& Gupta, A. K. (2010). ABC and VED analysis of the pharmacy store of a tertiary care teaching, research and referral healthcare institute of India. Journal of young pharmacists, 2(2), 201-205.

Çelikçapa, F. O. \& Şenol, G. (2015). Üretim Yönetimi. Bursa: Ekin Basım Yayın Dağıtım.

Odabaşı, Y. (2010). Sağlık Hizmetleri Pazarlaması. Eskişehir: Anadolu Üniversitesi Yayınları, (3.Bask1).

Ömürbek, N. \& Tunca, M. Z. (2013). Analitik hiyerarşi süreci ve analitik ağ süreci yöntemlerinde grup kararı verilmesi aşamasına ilişkin bir örnek uygulama. Süleyman Demirel Üniversitesi İktisadi ve İdari Bilimler Fakültesi Dergisi, 18(3), 47-70.

Özdemir, A. İ. \& Seçme, N. Y. (2009). İki aşamalı stratejik tedarikçi seçiminin bulanık topsıs yöntemi ile analizi. Afyon Kocatepe Üniversitesi İktisadi ve İdari Bilimler Fakültesi Dergisi, 11(2), 79-112.

Özgüven, N. (2011). Kriz döneminde küresel perakendeci aktörlerin performanslarının TOPSIS yöntemi ile değerlendirilmesi. Atatürk Üniversitesi İktisadi ve İdari Bilimler Dergisi, 25(2), 151-162.

Parsaei, S., Keramati, M., Zorriassatine, F. \& Feylizadeh, M. (2012). An order acceptance using FAHP and TOPSIS methods: A case study of Iranian vehicle belt production industry. International Journal of Industrial Engineering Computations, 3(2), 2112-224.

Partovi, F. Y. \& Anandarajan, M. (2002). Classifying inventory using an artificial neural network approach. Computers \& Industrial Engineering, 41(4), 389-404.

Pirankar, S. B., Ferreira, A.M., Vaz, F.S., Pereira-Antao, I., Pinto, N.R. \& Perni, S. G., (2014), Application of ABC-VED analysis in the medical stores of a tertiary care hospital, International Journal of Pharmacology Toxicology, 4(3),175-177.

Pund, S. B., Kuril, B. M., Hashmi, S. J., Doibale, M. K., \& Doifode, S. M. (2017). ABC-VED matrix analysis of Government Medical College, Aurangabad drug store. International Journal of Community Medicine and Public Health, 3(2), 469-472. 
Rachmania, I. N. \& Basri, M. H. (2013). Pharmaceutical inventory management issues in hospital supply chains. Management, 3(1), 1-5.

Ramanathan, R. (2006). ABC inventory classification with multiple-criteria using weighted linear optimization. Computers \& Operations Research, 33(3), 695-700.

Roy, R. N., Manna, S. \& Sarker, G.N., (2010), Applying management techniques for effective management of medical store of a public sector undertaking hospital, Indian Journal Prev. Soc. Med., 41(1),11-14.

Savaş, H. O. (2018). Özel Bir Hastanenin Ameliyathanesinin Stok Kontrolünde ABC. VED ve ABC-VED Matriks Analizinin Kullanımı. (Yayınlanmamış yüksek lisans tezi), İstanbul Yeniyüzyıl Üniversitesi, İstanbul.

Singh, S., Gupta, A. K. \& Devnani, M. (2015). ABC and VED analysis of the pharmacy store of a tertiary care, academic institute of the Northern India to identify the categories of drugs needing strict management control. Journal of young pharmacists, 7(2), 76-80.

Song, J. \& Zheng, J. (2015). The application of grey-TOPSIS method on teaching quality evaluation of the higher education. iJET, 10(8), 42-45.

Şahin, A. (2007). Yalın Üretimde Analitik Hiyerarşi Modelinin Uygulanabilirliği. (Yayınlanmamış yüksek lisans tezi), Gazi Üniversitesi, Ankara.

Taddele, B. W., Wondimagegn, A. A., Asaro, M. A., Sorato, M. M., Gedayi, B. G. \& Hailesilase, A. A. (2019). ABC-VEN matrix analysis of the pharmacy store in a secondary level health care facility in Arbaminch Town, Southern Ethiopia. Journal of Young Pharmacists, 11(2), 182-185.

Tanyaş, M. \& Baskak, M. (2013). Üretim Planlama ve Kontrol. İstanbul: İrfan Yayıncılık, (5.Baskı).

Tayyar, N., Akcanlı, F., Genç, E., \& Erem, I. (2014). BİST’e kayıtlı bilişim ve teknoloji alanında faaliyet gösteren işletmelerin finansal performanslarının analitik hiyerarşi prosesi (AHP) ve gri ilişkisel analiz (GİA) yöntemiyle değerlendirilmesi. Muhasebe ve Finansman Dergisi, (61), 19-40.

Tekin, M. (2003). Üretim Yönetimi. Konya: Günay Ofset, (2.Cilt).

Tengilimoğlu, D. (2012). Sağlık Hizmetleri Pazarlaması. Ankara: Siyasal Kitabevi.

Tengilimoğlu, D. \& Yiğit, V. (2017). Sağlık İşletmelerinde Tedarik Zinciri ve Malzeme Yönetimi. Ankara: Nobel Yayıncılık, (3.Baskı).

Tisinli, A., \& Savaş, O. (2019) Ameliyat odalarında stok kontrol yöntemleri: ABC, VED ve ABCVED matriks analizi. Sağlık ve Hemşirelik Yönetimi Dergisi, 6 (2), 101-109.

Türk, M. \& Şeker, M. (2011). Stratejik stok yönetimi: Bir kamu hastanesi örneği. Uluslararası İnsan Bilimleri Dergisi, 8(1), 713-727.

Uygun, S. (2016). Hastane İşletmelerinde Etkin Stok Yönetimi: İlaç Stoklarına Yönelik Bir Uygulama. (Yayınlanmamış yüksek lisans tezi). Süleyman Demirel Üniversitesi, Isparta. 
Uygun, S. \& Yiğit, V. (2016). Hastane işletmelerinde etkin ilaç stok kontrolü: Pamukkale Üniversitesi Hastanesinde bir uygulama. Balkan Sosyal Bilimler Dergisi, 742-751.

Uygun, S.,\& Yiğit, V. (2017). Hastane işletmelerinde etkin stok yönetimi: İlaç stoklarına yönelik bir uygulama. Mehmet Akif Ersoy Üniversitesi, Sosyal Bilimler Enstitü Dergisi, 9(18), 288307.

Vaz, F. S., Ferreira, A. M., Kulkarni, M. S., Motghare, D. D. \& Pereira-Antao, I. (2008a). A study of drug expenditure at a tertiary care hospital: An ABC-VED analysis. Journal of Health Management, 10(1), 119-127.

Vaz, F. S., Ferreira, A. M., Pereira-Antao, I., Kulkarni, M. S. \& Motghare, D. D. (2008b). Application of inventory control techniques for drug management at a rural health centre. Indian $J$ Prev Soc Med, 39(3), 120-23.

Wandalkar, P., Pandit, P. T. \& Zite, A. R. (2013). ABC and VED Analysis of the drug store of a tertiary care teaching hospital. Indian Journal of Basic and Applied Medical Research, 3(1), 126-131.

Wang, H-C., Chiu, W-P. \& Wu, S-C. (2015). Qos-driven selection of web service considering group preference. Computer Networks, 93(1), 111-124.

Yarar, O. \& İnce, Ö. (2017). Sağlık Kuruluşlarında Hasta Hizmetleri. Ankara: Güneş Tıp Kitabevleri.

Yeşilyurt, Ö. (2014). Sağlık Sektöründe Stok Kontrol Faaliyetlerinin ABC ve VED Analizleriyle Değerlendirilmesi: Isparta Devlet Hastanesi Örneği. (Yayınlanmamış yüksek lisans tezi). Süleyman Demirel Üniversitesi, Isparta.

Yıldırım, B. F. \& Önder, E. (2015). Operasyonel, Yönetsel ve Stratejik Problemlerin Çözümünde Çok Kriterli Karar Verme Yöntemleri. Bursa: Dora Basım-Yayın Dağıtım, (2. Baskı).

Yiğit, V. (2014). Hastanelerde stok kontrol analizi: Akdeniz Üniversitesi Hastanesinde bir uygulama. Sayıştay Dergisi, 93, 105-128.

Yiğit, V., Dikmetaş, E., Ağırbaş, İ. \& Tengilimoğlu, D. (2010). ABC and VED Analysis In Hospital Material Management Systems. In Proceeding of Sixth International Conference on Health Care Systems (202-206).

Yiğit, A. \& Yiğit, V. (2019). Tibbi malzeme stok kontrolünde ABC ve VED analizi: Sağlık Bakanlığı Hastanelerinde bir araştırma. Süleyman Demirel Üniversitesi Vizyoner Dergisi, 10(24), 254-263.

Yilmaz, F. (2018). The drug inventories evaluation of healthcare facilities using ABC and VED analyzes. Istanbul Journal of Pharmacy, 48(2), 43-48.

Zhou, P. \& Fan, L. (2007). A note on multi-criteria ABC inventory classification using weighted linear optimization. European Journal of Operational Research, 182(3), 1488-1491. 


\title{
MULTI-CRITERIA INVENTORY CLASSIFICATION IN THE HEALTHCARE SECTOR USING ABC-VED AHP AND TOPSIS METHODS
}

\author{
Zehra BÖKER* \\ Onur ÇETIN ${ }^{* *}$
}

Inventory control has vital importance for companies as it affects both costs and service level. Inventory control is not only important for manufacturing sector but also for service sectors. Health sector has some distinctive difficulties when compared with other service sectors. Time pressure may be regarded as one of these difficulties. If required services can not be provided to the patient on time, the consequences may be harmful (Tengilimoğlu, 2012; Odabaş1, 2010). Providing the required service is mostly associated with inventory control system. Due to this fact, managing inventories such as medicines has great importance for hospitals. So it is obvious that companies in the health sector have to use more comprehensive inventory control systems compared with other sectors. $\mathrm{ABC}$ analysis is a well-known method for inventory classification. In ABC analysis the criteria used for inventory classification are demand and cost of an item. The most known inventory control method for health sector is $\mathrm{ABC}-\mathrm{VED}$ analysis which uses cost, demand and importance/criticality as classification criteria (Devnani, Gupta \& Nigah, 2010). ABC-VED analysis widely used in inventory classification in health sector (Wandalkar, Panditvd \& Zite, 2013; Pirankar, et al., 2008b; Singh, Gupta \& Devnani, 2015; Karagöz \& Y1ldız, 2015; Fitriana, Satria \& Setiawan, 2018; Savaş, 2018; Yılmaz, 2018; Yiğit \& Yiğit, 2019; Tisinli \& Savaş, 2019; Hussain, Siddharth \& Arya, 2019; Taddele et al., 2019). While many criteria including supplier criteria is used in inventory classification in other sectors, research using more than these three criteria is limited in health sector. In order to provide required health service on time supplier risk can be regarded as an important criterion. This research aims to propose a multi criteria decision model for inventory classification of medicines in health sector by adding supplier risk criteria to ABC-VED analysis.

* Trakya University, Department of Business Administration, E-mail:zehra_boker@hotmail.com

** Trakya University, Department of Business Administration, E-mail:onurcetin@trakya.edu.tr 
In this research, $\mathrm{ABC}, \mathrm{ABC}-\mathrm{VED}, \mathrm{AHP}$ and TOPSIS methods are used. Both AHP and TOPSIS are known as multi criteria decision making methods (Yıldırım ve Önder, 2015). The usage of AHP, TOPSIS and ABC-VED analysis together for inventory classification in health sector is limited. In the research initial inventory classification is conducted by ABC-VED method. In the initial ABC classification, $10 \%$ of all items existed in A class and they accounted for $80 \%$ of annual consumption value (10\%-80\%). For B items $13 \%$ of the items accounted for $15 \%$ of annual consumption value (13\%-15\%) and for $\mathrm{C}$ items it was $77 \%$ to $5 \%$. In initial ABC-VED Matrix analysis, it is observed that $\% 35$ of the items existed in the first category and they accounted for $89 \%$ of annual consumption value. When it comes to second category, it is seen that $31 \%$ of all items existed in the second category and they accounted for $9 \%$ of annual consumption value. Items in the third category accounted for only $2 \%$ of annual consumption value. After initial ABC-VED analysis, supplier risk is added as a new criterion for inventory classification. Cost, demand and supplier risk criteria are weighted using AHP in order to determine their relative importance for inventory classification. Results of AHP method show that the most important criteria for inventory classification was cost $(0,495)$, the second important one was demand $(0,400)$ and the least important one was supplier risk $(0,103)$. Items are sorted according to these three criteria with TOPSIS method. After sorting all items using the weights and scores of these three criteria using TOPSIS method, a new sorting of items is obtained. Items in this sorting clustered according to their cumulative consumption value such as the same in initial $\mathrm{ABC}$ analysis. It is observed that new $\mathrm{ABC}$ classes and initial ABC classes were slightly different. The class of many items changed. One of the reasons of this change was adding the supplier risk criteria. According to new ABC classification, $16 \%$ of all items existed in A class and they accounted for $80 \%$ of annual consumption value (16\%-80\%). For B items it was 17\%-15\% and for C items it was 67\%-5\%. In new ABC-VED classification, number of items in the first category increased while annual consumption value remained nearly same when compared with initial ABC-VED classification.

Supplier risk is an important criterion for inventory classification and used in many sectors. However, in health sector cost, demand and critically are most widely used criteria. In this research results of classical ABC-VED analysis is compared with the results of the proposed method which conducts a new $\mathrm{ABC}$-VED analysis by adding the supplier risk criteria besides the criteria used in ABC-VED analysis. Results show that adding supplier risk as new criteria changes ABC-VED classification significantly. According to the results, the number of items in the first category increases. As first category is about the riskiest items for a health facility, this finding is important. This means that the proposed method using three criteria may be useful for hospitals in inventory classification. Results obtained by initial and new ABC-VED classifications are compared with the literature as well. It can be said that, enhancing the criteria used for inventory classification in further research may be more useful.

Keywords: Healthcare sector, ABC-VED, AHP, TOPSIS, Inventory Control. 